\title{
Seep communities from two mud volcanoes in the deep eastern Mediterranean Sea: faunal composition, spatial patterns and environmental control
}

\author{
Bénédicte Ritt ${ }^{1,2, *}$, Daniel Desbruyères ${ }^{1}{ }$, Jean-Claude Caprais ${ }^{1}$, Olivier Gauthier ${ }^{3}$, \\ Livio Ruffine ${ }^{1}$, Roselyne Buscail ${ }^{4}$, Karine Olu-Le Roy ${ }^{1}$, Jozée Sarrazin ${ }^{1}$ \\ ${ }^{1}$ Ifremer Brest, REM/EEP \& REM/GM, Institut Carnot Ifremer-EDROME, BP 70, 29280 Plouzané, France \\ ${ }^{2}$ Biology Department, Temple University, 1900 North 12th Street, Philadelphia, Pennsylvania 19122, USA \\ ${ }^{3}$ IUEM, UBO, Technopôle Brest-Iroise, Place Nicolas Copernic, 29280 Plouzané, France \\ ${ }^{4}$ CEFREM, CNRS, UMR 5110, Université de Perpignan, 52, avenue Paul Alduy, 66860 Perpignan, France
}

\begin{abstract}
The Mediterranean Sea constitutes a unique environment to study cold-seep ecosystems due to the presence of different geodynamic settings, from an active margin along the Mediterranean Ridge (MR) to a passive margin in the Nile Deep-Sea Fan (NDSF). We attempted to identify the structure of benthic communities associated with the Napoli and Amsterdam mud volcanoes (MVs) located on the MR and to establish the links between faunal distribution and environmental conditions at different spatial scales. Comparison between the $2 \mathrm{MVs}$ revealed that the faunal distribution seemed to be mainly controlled by the characteristics of the microhabitats. On both geological structures, the variability between the different microhabitats was higher than the variability observed between replicates of the same microhabitat, and the distribution of macrofauna was apparently linked to gradients in physico-chemical conditions. The peripheral sites from Napoli were generally more oxygenated and harboured lower species richness than the active sites. The reduced sediment microhabitat from Amsterdam presented the highest methane concentrations and was mainly colonised by symbiont-bearing vesicomyid bivalves and heterotrophic dorvilleid polychaetes. Overall, a higher taxonomic diversity was observed on Napoli. Substratum type was hypothesised to be the second factor influencing faunal distribution. The results of this study highlight the high heterogeneity of faunal communities associated with seep ecosystems within this region and the need to pursue investigations at various spatial and temporal scales.
\end{abstract}

KEY WORDS: Mediterranean Ridge $\cdot$ Cold seeps $\cdot$ Benthic fauna $\cdot$ Environmental conditions Diversity indices $\cdot$ Microhabitats

Resale or republication not permitted without written consent of the publisher

\section{INTRODUCTION}

Cold seeps are geological features generated by mud, water and gas emissions occurring on the seafloor (Kvenvolden \& Rogers 2005, Judd \& Hovland 2007). Since their discovery on the Florida Escarpment in the Gulf of Mexico (Paull et al. 1984), more than 40 seep sites with chemosynthesis-based communities have been reported throughout the world's oceans, at different depths (Sibuet \& Olu 1998, Levin 2005, Campbell 2006). These sites are characterised by the formation of peculiar geological structures such as pockmarks, brine lakes, mud volcanoes or gas flares (Milkov 2000, Hovland et al. 2002, Levin 2005, Judd \& Hovland 2007).

The Mediterranean Sea constitutes a unique environment to study cold-seep ecosystems due to the presence of different geodynamic settings, from an 
active margin along the Mediterranean Ridge (MR) to a passive margin in the Nile Deep-Sea Fan (NDSF). The eastern Mediterranean Sea is presently undergoing complex evolution due to the subduction of the African plate beneath the southern Eurasian plate. The MR is a particularly prominent morphostructural feature along this major converging system. This large arc-shaped, accretionary wedge extends for more than $1500 \mathrm{~km}$ in length and 200 to $250 \mathrm{~km}$ in width (Limonov et al. 1996). The presence of fluid seepages related to seabed structures along this ridge was first discovered south of Crete (Cita et al. 1981). Since then, mud diapirs and mud volcanoes (MVs) have been identified at several localities in the central MR (Cita \& Camerlenghi 1990, Ivanov et al. 1996, Huguen et al. 2004), on the Anaximander Mountains (Woodside et al. 1998, Zitter et al. 2003), along the Florence Rise (Woodside et al. 2002, Zitter 2004) and in the Levant Basin (Coleman \& Ballard 2001). The most recent investigations were focused on the NDSF, off the coast of Egypt, an area characterised by the presence of a heavily sedimented margin (Bellaiche et al. 2001, Mascle et al. 2001, 2006, Loncke et al. 2004). However, the first evidence of benthic communities based on chemosynthetic processes was found on the Napoli MV (Corselli \& Basso 1996). It is now known that several of the MR sites (Salas \& Woodside 2002, Olu-Le Roy et al. 2004, Werne et al. 2004) as well as those in the NDSF are colonised by various chemosynthesis-based faunal assemblages (Huguen et al. 2005, Zitter et al. 2005, Dupré et al. 2007, Ritt et al. 2011).

The first data on Mediterranean cold-seep communities were acquired during the French-Dutch MEDINAUT cruise (1998) in 2 regions: the Olimpi mud field and the Anaximander Mountains (Salas \& Woodside 2002, Olu-Le Roy et al. 2004, Werne et al. 2004). These communities are dominated by small bivalves from 2 families (Mytilidae and Vesicomyidae) common to cold-seep environments (Duperron et al. 2009, Krylova \& Sahling 2010, Oliver et al. 2011) and 2 others (Lucinidae and Thyasiridae) known from shallower sulphide-rich habitats including seeps (Dando \& Southward 1986, Cary et al. 1989a, Olu-Le Roy et al. 2004, Brissac et al. 2011). Siboglinid polychaetes belonging to the clades Obturata ( $\mathrm{La}$ mellibrachia anaximandri, Southward et al. 2011) and Frenulata (Siboglinum sp.) as well as heterotrophic mega- and macro-faunal species have also been observed. The fauna seems to be concentrated at the summit of the MVs, where the seepage activity is usually the greatest, even in the brine lake zone on Napoli (Olu-Le Roy et al. 2004). Typical deep-sea taxa (fish, urchins, sponges) benefit from the increased biomass found near the seeps (Olu-Le Roy et al. 2004). The species richness of the symbiont-bearing fauna observed during the MEDINAUT cruise was much higher than that found in similar communities at comparable depths in other oceans (Sibuet \& Olu-Le Roy 2002). While environmental factors such as methane, sulphide or oxygen concentrations have been suggested as structuring factors in seep communities worldwide (Barry et al. 1997, Olu et al. 1997, Levin \& Gage 1998, Sahling et al. 2002, Levin et al. 2003, 2010, Niemann et al. 2006, Olu-Le Roy et al. 2007, Cordes et al. 2010), those from the eastern Mediterranean Sea have been studied only recently (Ritt et al. 2010, 2011).

In 2007, various cold-seep ecosystems in the Mediterranean Sea were investigated during the MEDECO cruise. The present study aims to describe the structure of benthic communities associated with the Napoli and Amsterdam MVs located between 1940 and $2025 \mathrm{~m}$ depth on the MR and to establish the links between faunal distributions and environmental conditions at the microhabitat (several meters) to MV scale (several hundred meters). We aimed to understand the factors that influence the structure and diversity of seep communities in the Mediterranean Sea, using a mostly family-level taxonomic resolution.

\section{MATERIALS AND METHODS}

The first studies concerning the regions of interest were done during the MEDINAUT (1998), NAUTINIL (2003) and M70/3 (2006) cruises. Bathymetric maps and observations made during these cruises were used to decide on the dive strategy for the MEDECO cruise. The first leg of MEDECO took place from 7 to 31 October 2007 on the RV 'Pourquoi Pas?' with the remotely operated vehicle (ROV) 'Victor6000'. During this cruise, different deep-sea ecosystems of the Mediterranean Sea were visited, including the Napoli and Amsterdam MVs (Fig. 1). Three dives, totalling $87 \mathrm{~h}$ of bottom time, were dedicated to sampling these $2 \mathrm{MVs}$.

\section{Study areas}

The Olimpi field, located south of Crete (Fig. 1a-c), is the largest known MV field on the MR. Its geomorphology has been extensively studied since its discovery in 1988 (Camerlenghi et al. 1992, Ivanov et al. 1996, Huguen et al. 2004). Most of the MVs found in 


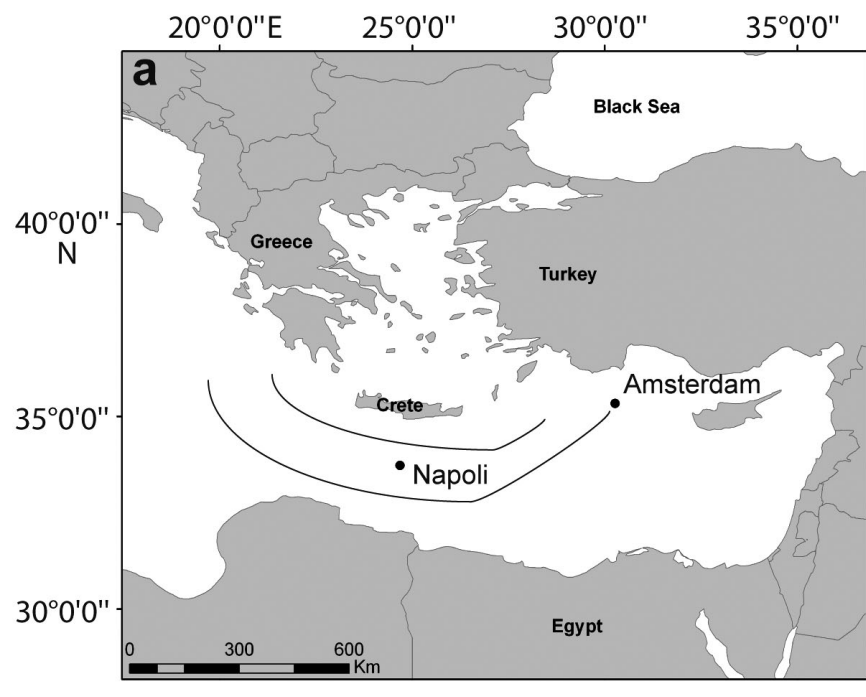

Fig. 1. (a) Eastern Mediterranean Sea, showing the location of the sampling sites and the position of the Mediterranean Ridge (black lines). Bathymetric maps, tracks of the remotely operated vehicle dives, location of the microhabitats and the reference sites on $(b, c)$ the Napoli mud volcano (MV), located in the Olimpi field at $33^{\circ} 43.75^{\prime} \mathrm{N}, 24^{\circ} 40.95^{\prime} \mathrm{E}$ and (d, e) the Amsterdam $\mathrm{MV}$, located in the Anaximander Mountains at $35^{\circ} 20.10^{\prime} \mathrm{N}, 30^{\circ} 16.09^{\prime} \mathrm{E}$. Both MVs were sampled during the MEDECO cruise (Leg 1) in 2007
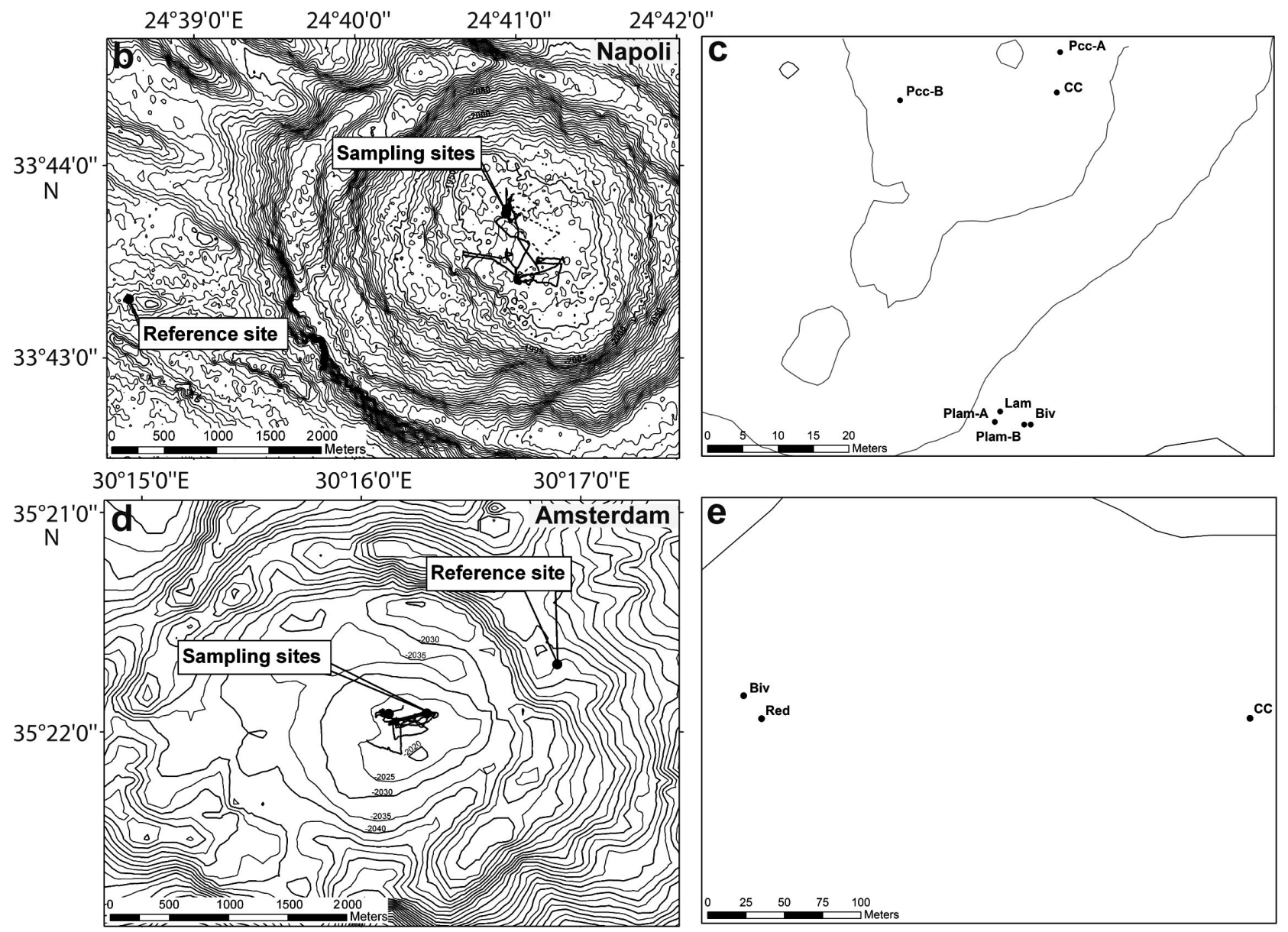

this field are dome-shaped. Located at $1950 \mathrm{~m}$ depth, Napoli is among the largest MVs on Olimpi, reaching $1000 \mathrm{~m}$ across and $200 \mathrm{~m}$ high. It is surrounded by irregular mud flows and circular depressions (Fig. 1b) and is characterised by the occurrence of fresh mud flows, brine pools, authigenic carbonate crusts (Huguen et al. 2005) and by intense degassing on its summit (Charlou et al. 2003). Two dives were entirely dedicated to sampling the macro- and meiofauna and characterising the environmental conditions at the immediate periphery of the centre $\left(33^{\circ} 43.75^{\prime} \mathrm{N}, 24^{\circ} 40.95^{\prime} \mathrm{E}\right)$ at $1940 \mathrm{~m}$ depth. 
Located south of Turkey, the Anaximander Mountains are shaped by a complex of $3 \mathrm{MVs}$, rising more than $100 \mathrm{~m}$ above the seafloor, generally identified as conical topographic features to which the Amsterdam MV belongs (Zitter et al. 2005; Fig. 1a,d,e). This $\mathrm{MV}$, located at a maximum depth of $2040 \mathrm{~m}$, is ellipse-shaped and reaches $3 \mathrm{~km}$ across and $100 \mathrm{~m}$ high. It has a very uneven terrain with depressions and abrupt scarps, particularly on its summit, probably caused by an erupted mud flow of $300 \mathrm{~m}$ thickness (Woodside et al. 1998). The surface of Amsterdam is characterised by the presence of carbonate crusts, muddy areas and large rock clasts (i.e. rock fragments coming from deeper layers and expulsed to the seafloor with fluid and gas emissions). In contrast to the Napoli MV, no brine pools have ever been observed on this MV (Zitter et al. 2005), whereas carbonate crust-associated benthic communities have been reported (Olu-Le Roy et al. 2004). Faunal sampling and environmental characterisation were performed during 1 long dive at 2 different sites located at the immediate periphery of the centre $\left(35^{\circ}\right.$

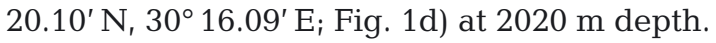

\section{Sampling sites}

The 2 MVs harboured a mosaic of visually distinguishable microhabitats. Two of the sampled microhabitats were common to both MVs: (1) brown sediments with high density of bivalve shells on the chaotic sediment surface (Biv, Fig. 2a,g); and (2) carbonate crusts (CCs, Fig. 2c,i). The CCs presented different morphologies; they formed large and thick pavements on the sediment surface and also within sediments on Napoli, while they were more superficial and fragile on Amsterdam. The Lamellibrachia microhabitat (Lam) was only sampled on Napoli (Fig. 2b). These Siboglinidae polychaetes were also observed on Amsterdam but they were located under $\mathrm{CCs}$ and were therefore difficult to sample. Bubble emissions were only observed on Amsterdam reduced sediments, constituting the reduced sediment microhabitat (Red, Fig. 2h) located in a depression. On Napoli, additional samples were taken in the periphery of the Lamellibrachia microhabitat (Plam, Fig. 2d) as well as at the periphery of the CC microhabitat (Pcc, Fig. 2e) in settings resembling the Biv microhabitat. These sites were sampled to determine possible gradients between active (Lam, CC) and peripheral (Plam, Pcc) sites. These additional microhabitats were located from 2 to $22 \mathrm{~m}$ away from the active microhabitats (Table 1, Fig. 1c). The so-called 'active' microhabitats were those characterised by the presence of visible chemosynthetic fauna (e.g. $L$. anaximandri), specific geological features (e.g. CCs) or seepage activity (e.g. bubble emissions or black sediments). The peripheral samples were taken on the edge of the active areas on the MVs and were distinct from the reference samples. On Napoli, the 'active' sites and their peripheries were included within a $30 \mathrm{~m}$ diameter circle localised approximately $250 \mathrm{~m}$ away from brine evidences and $500 \mathrm{~m}$ from the central brine lake. On Amsterdam, Biv and Red were very close to each other $(\sim 17 \mathrm{~m})$ and separated by $300 \mathrm{~m}$ from the $\mathrm{CC}$ microhabitat (Fig. 1e). Finally, the reference samples sensu stricto (Ref) were collected outside of each $M V$, a few thousand metres from the centre, and away from any seepage activity (Fig. 1b,d). Contrary to the microhabitats on the MVs, 1 unique sample was sampled at each reference site using a box-corer launched from the surface.

\section{Sampling procedures}

Environmental characterisation of each microhabitat was conducted before faunal sampling to avoid any disturbance that could be caused by the latter. In situ measurements of total sulphides $\left(\mathrm{H}_{2} \mathrm{~S}+\mathrm{HS}^{-}+\right.$ $\mathrm{S}^{2-}$ ) were performed with CHEMINI, a miniaturised deep-sea chemical analyser (Vuillemin et al. 2009). CHEMINI's sample inlet was deployed for $20 \mathrm{~min}$ above the organisms and as close as possible ( 1 to $2 \mathrm{~cm}$ ) to the seafloor using the ROV manipulator arm. Water and sediment samples were then taken for chemical analyses using the PEPITO water sampler and tube corers (30 $\mathrm{cm}$ long; $5.4 \mathrm{~cm}$ inner diameter), respectively. PEPITO collects water in $200 \mathrm{ml}$ titanium bottles and sampled at the same locations as those chosen for the CHEMINI measurements. Sediment tube cores were split horizontally on board, and porewater was extracted by centrifugation of each sediment layer (every $0.5 \mathrm{~cm}$ for the first $2 \mathrm{~cm}$, then every $\mathrm{cm}$ until $10 \mathrm{~cm}$ and every $2 \mathrm{~cm}$ until the end of the core) to measure chloride and sulphate concentrations. Sampling details for each microhabitat, periphery and reference site are given in Table 1. Unfortunately, due to technical and time constraints, the CHEMINI chemical sampling could not be completed on Amsterdam (no sulphide analysis was made).

The epi- and endofauna were sampled with blade corers $\left(200 \mathrm{~cm}^{2}\right)$ at all soft sediment sites (Fig. 2a,b,d,e,g,h). The number of samples for each 

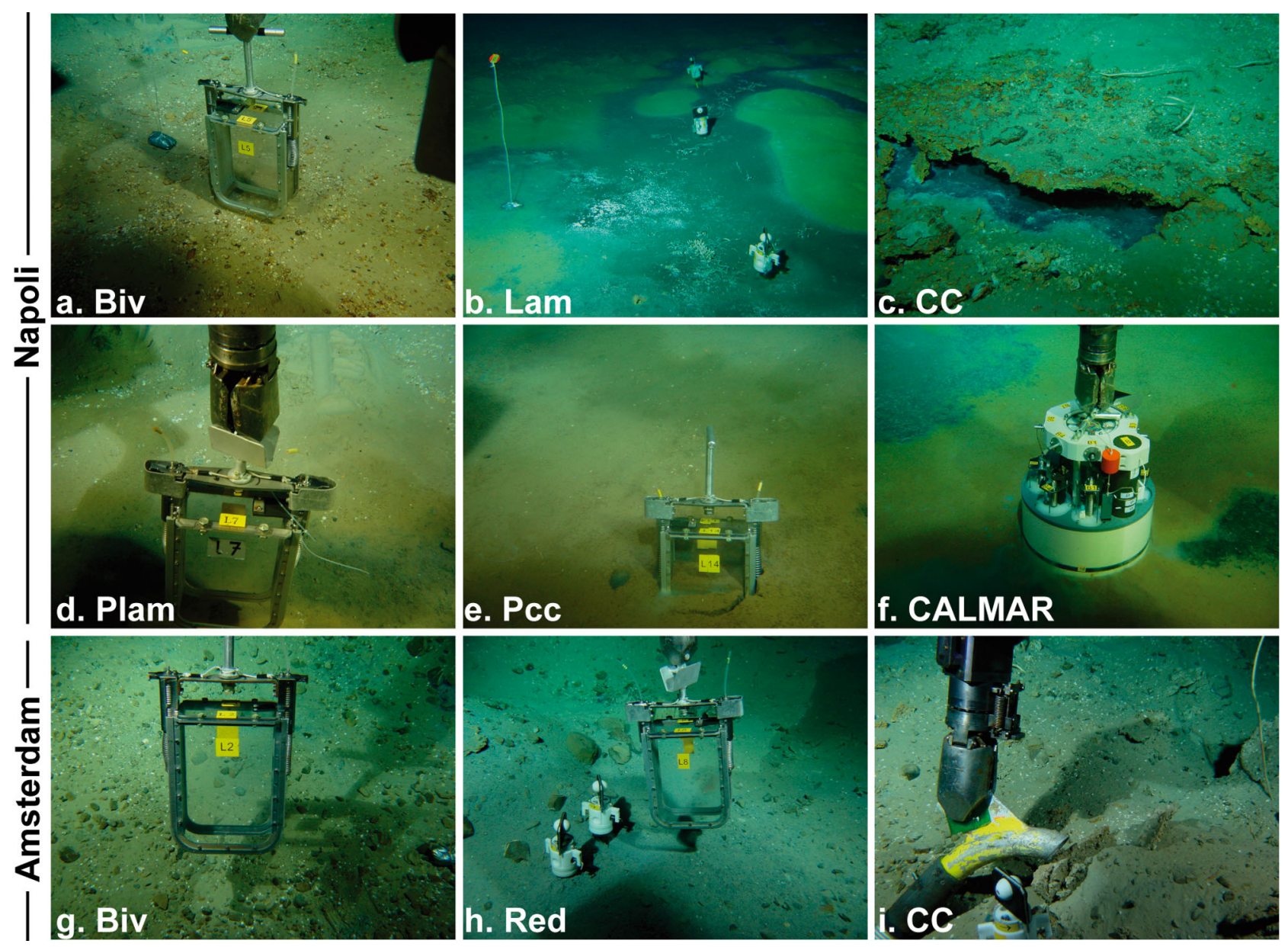

Fig. 2. Photographs of the typical microhabitats sampled on (a-e) Napoli and (g-i) Amsterdam mud volcanoes (MVs): (a) bivalve shells (Biv), (b) Lamellibrachia (Lam), (c) carbonate crusts (CC), brown sediments from (d) the Lam periphery (Plam), and (e) the CC periphery (Pcc) on the Napoli MV. (f) The CALMAR benthic chamber was deployed above 1 Lamellibrachia patch on Napoli. (g) Biv, (h) reduced sediments (Red) and (i) CC on the Amsterdam MV. Blade corers were used to sample fauna in soft sediments $(a, d, e, g, h)$ while the remotely operated vehicle suction sampler was used to sample the epifauna on the carbonate crusts (i). All microhabitats were sampled during the MEDECO cruise (2007)

microhabitat varied, depending on the time and number of corers available during a particular dive (Table 1). Due to these limitations, endofauna in each reference site was only sampled with a single box core, triggered from the surface. On carbonate crusts, the ROV suction sampler was used to collect the epifauna (Fig. 2i) before collecting pieces of carbonate with its manipulator arm (Fig. 2c,i). Each crust sample was put in an individual sampling box (Table 1).

In addition to the systematic sampling within the microhabitats, 2 CALMAR benthic chambers (Caprais et al. 2010) were deployed on Napoli by the ROV manipulator arm; the first was deployed above live Lamellibrachia anaximandri (CALMAR A, Fig. 2f) and the second was deployed a few metres away on reduced sediments devoid of siboglinids (CALMAR B, not shown), identified as a peripheral site. These benthic chambers were equipped with 2 independent oxygen probes (Aanderaa optodes) and 6 water sampling units. The probes were used to measure in situ dissolved oxygen consumption by the fauna while the water samples were used to validate the oxygen data and to calculate carbon dioxide and methane emission fluxes.

\section{Physico-chemical analyses}

The $200 \mathrm{ml}$ water samples from PEPITO were used to determine $\mathrm{pH}$ as well as methane, oxygen, sulphate and chloride concentrations (Table 1). Measurements 


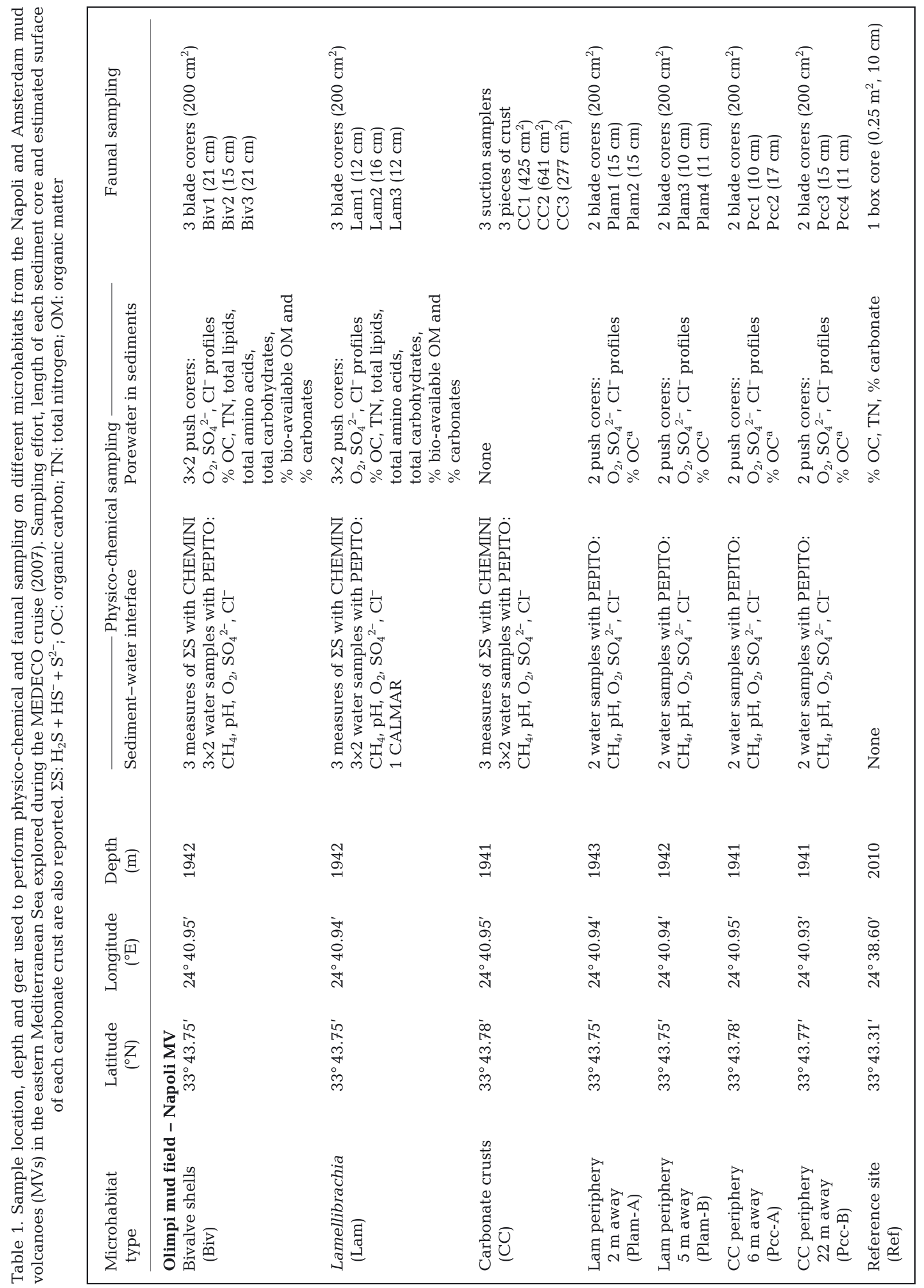




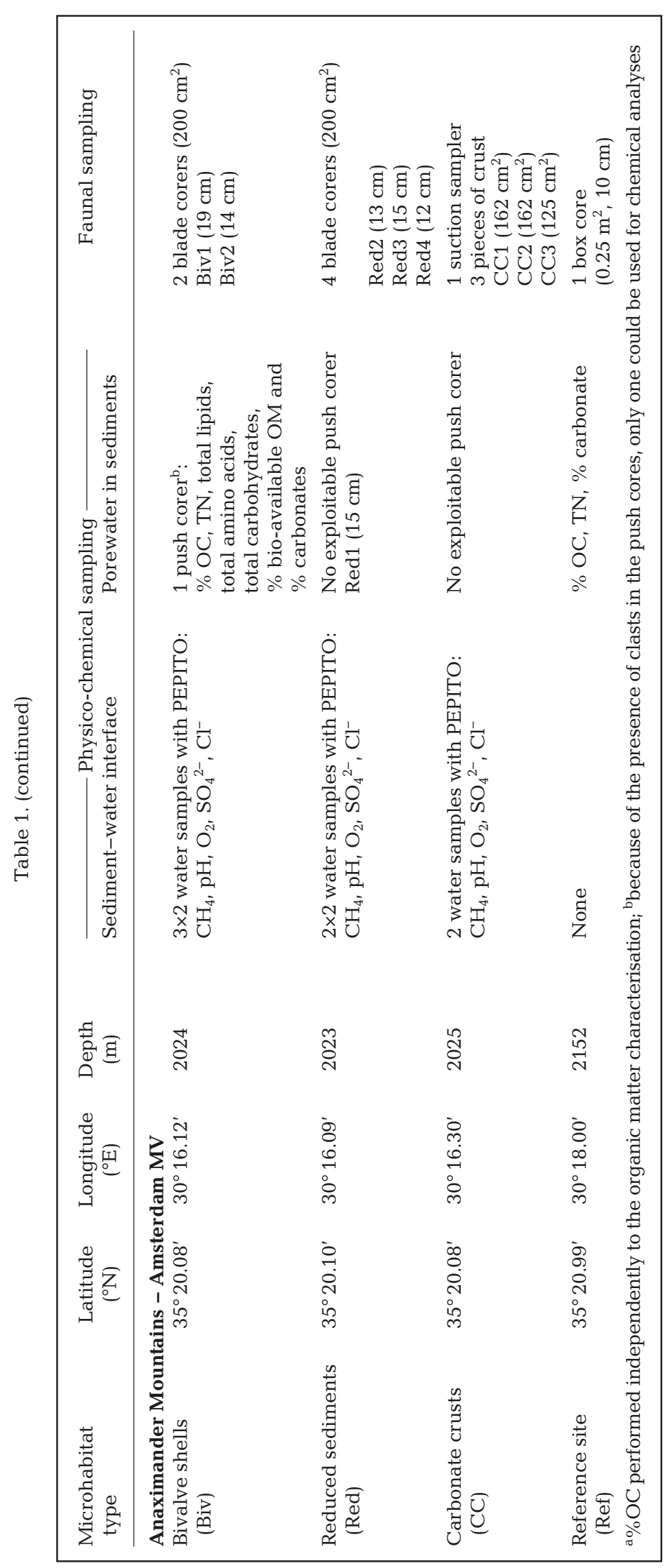

of $\mathrm{pH}$ were performed on board with a $\mathrm{pH}$ meter linked to a glass electrode (Metrohm) after calibration performed at $25^{\circ} \mathrm{C}$ using NBS standard solutions at $\mathrm{pH} \sim 7$ and $\sim 9$ (Metrohm refs. 6.230.110 and 6.307.120, respectively). Reproducibility of the method was $\pm 0.01 \mathrm{pH}$ units. Methane concentrations were measured in the laboratory using the headspace technique coupled with a gas chromatograph equipped with a flame-ionisation detector (error of $4 \%$, see method in Sarradin \& Caprais 1996). Dissolved oxygen concentrations (in water samples) were determined using the Winkler method (Winkler 1888) adapted for small volumes, with an error of $4 \%$. Sulphate and chloride concentrations (in water samples as well as in porewater extracted from sediment slices) were measured using an ionic chromatograph on an isocratic system (DX 120, DIONEX). Intact cores with supernatant water were used for oxygen measurements. Chemical differences in average surface dissolved oxygen, methane, sulphate and chloride concentrations as well as $\mathrm{pH}$ between the $2 \mathrm{MVs}$ were evaluated with Mann-Whitney tests. However, due to the small number of samples ( $\mathrm{n}=3$ for each microhabitat), statistical comparison at a smaller scale, i.e. between the 2 common microhabitat types (Biv and CC) was not performed because of insufficient power.

The water sampled by CALMAR was immediately collected upon recovery. Dissolved oxygen consumption was calculated as explained above for the PEPITO samples. Total dissolved inorganic carbon (DIC) was determined using infrared (NDIR) gas analyses (Kaltin et al. 2005), and methane was analysed using headspace gas chromatography (Sarradin \& Caprais 1996). Fluxes were calculated from the slopes of the linear regressions obtained with oxygen, methane and carbon dioxide concentrations versus time (Caprais et al. 2010).

Oxygen profiles within interstitial water (tube cores) were obtained with a microsensor (OX 100) coupled to a picoammeter (PA 2000, Unisense) and a micro-manipulator using profix data acquisition software (Unisense). The resolution of the sensor was $<200 \mu \mathrm{m}$. Kendall rank correlations $(\tau)$ were computed between mean sulphate and chlorinity profiles within Lam, Biv and $\mathrm{P}(\mathrm{lam}+\mathrm{cc})$ microhabitats from Napoli. The characterisation of the chemistry within the sediments is detailed in 'Supplement 1: Results' at www.intres.com/articles/supp/m466p093_supp.pdf. 


\section{Descriptors of the organic matter in sediments}

Total nitrogen, carbon and organic carbon concentrations (TN, TC and TOC, respectively) were measured using freeze-dried, milled sediment subsamples. Homogenised, weighed samples were analysed in an automatic CN-analyser (LECO 2000), after acidification with $2 \mathrm{~N} \mathrm{HCl}$ (overnight at $50^{\circ} \mathrm{C}$ ) to remove carbonates prior to organic carbon analyses (Cauwet et al. 1990). Precision was about $2 \%$ for TOC and TN measurements, and $0.3 \%$ for TC. Calcium carbonate content was calculated from mineral carbon (TC-OC) using the molecular mass ratio $\left(\mathrm{CaCO}_{3}: \mathrm{C}=100: 12\right)$. Percentages of organic carbon from additional samples (footnote 'a' in Tables 1 \& 3) were analysed with a LECO WR 12 autoanalyser after sediment decarbonation with $6 \mathrm{~N} \mathrm{HCl}$. These analyses were performed independently from organic matter (OM) characterisation.

The C:N ratio was estimated to determine the origin and degradation stage of OM. Total hydrolysable amino acids were assayed by a colorimetric method on the fraction hydrolysed by $6 \mathrm{~N} \mathrm{HCl}$ for $16 \mathrm{~h}$ at $110^{\circ} \mathrm{C}$. Absorption of the products resulting from the amino acid-ninhydrin reaction was measured at $570 \mathrm{~nm}$ using a Beckman spectrophotometer (precision of $15 \%$; Stevenson \& Cheng 1970). Total lipids were measured by a colorimetric method after extraction with a 2:1 (v:v) chloroform:methanol mixture. Absorption of the products was measured at $520 \mathrm{~nm}$ with a Beckman spectrophotometer (precision of $10 \%$; Barnes \& Blackstock 1973). Total carbohydrates were measured by a colorimetric method on the fraction hydrolysed by $3 \mathrm{M} \mathrm{H}_{2} \mathrm{SO}_{4}$. Absorption of the products resulting from the anthrone-sulphuric acid reaction was measured at $625 \mathrm{~nm}$ using a Beckman spectrophotometer (precision of $8 \%$; Brink et al. 1960). The biopolymeric fraction of OM calculated as the sum of carbohydrate, protein and lipid contents was used as an index of the potentially available fraction for benthic consumers (Fichez 1991). This fraction is hereafter called 'bio-available OM'.

\section{Faunal sorting and identification}

Sediments from blade corers were processed as described by Ritt et al. (2010, 2011), except for the Lam cores that could not be sliced due to the presence of Lamellibrachia tubes on the whole length of the cores and were thus considered a single slice. Furthermore, cores from the reference sites were split by sections to $10 \mathrm{~cm}$ depth. It would have been preferable to analyse the distribution up to $\sim 20 \mathrm{~cm}$ to be comparable to the maximum depths obtained with the blade corers and also to get the best representation of the vertical distribution at these sites, but due to different sampling strategies, we only had access to the first $10 \mathrm{~cm}$, leading to a probable underestimation. A great proportion of the endofaunal biomass in background sediments can be found below $20 \mathrm{~cm}$ depth at certain deep-sea sites (Jensen 1992, Dando et al. 2008). In addition, because the $250 \mu \mathrm{m}$ mesh used here is inadequate for meiofaunal sampling (which usually requires 32 to $62 \mu$ mesh; Hessler \& Jumars 1974, Thistle 2003, Van Gaever et al. 2006), we focused on macrofauna sensu stricto $(>250 \mu \mathrm{m}$, Hessler \& Jumars 1974). Any meiofaunal taxa such as Nematoda, Copepoda and Ostracoda were treated separately and are detailed in 'Supplement 1: Materials and methods'. Taxonomic determination was achieved at the family level for most of the taxa except for Demospongia, Hexactinellida, Scyphozoa, Polyplacophora, Nemerta, Leptostraca, Echinoida, Terebellida and Nematoda.

The CC samples were processed as described by Ritt et al. (2011) to assess surface area and arearelated indicators such as density (estimation of the number of ind $\mathrm{m}^{-2}$ ) and biomass. However, because it does not take relief into account, this method may underestimate total surface area and in turn, overestimate density and biomass. On the other hand, carbonates were not broken to collect potential endofauna, leading to a possible underestimation of faunal abundance.

\section{Measurement of taxonomic diversity at different spatial scales}

Within-microhabitat $(\alpha)$ and between-microhabitat ( $\beta$ ) diversity were estimated for all microhabitats as previously described by Ritt et al. (2011). Organisms from the whole cores and from the carbonate crusts (i.e. endo- and epifauna) were considered for these community analyses.

\section{$\alpha$-diversity}

The $\alpha$-diversity analyses were performed at the family level; undetermined families, individuals or larvae were removed from the dataset because of the probability that they belonged to a family already listed. This may have resulted in an underestimation of the taxonomic richness. However, there were 
3 exceptions, including the 'undetermined Gastropoda' found at the periphery of the Lamellibrachia microhabitat from Napoli and at the reference site from Amsterdam, for which no other Gastropoda families were observed. There were also 'undetermined Sipuncula' and 'undetermined Tanaidacea', both observed in the reference site of Napoli with no other families. We chose to slightly under-estimate the taxonomic richness rather than to over-estimate it.

Individual-based and sample-based rarefaction curves were computed as in Ritt et al. (2011): first with macrofaunal datasets for each microhabitat at both MVs and then with pooled data excluding reference sites away from each MV, and separating the 'active' from the peripheral sites on Napoli. Expected richness for an effort of 50 individuals (ES50) was used to compare microhabitat richness at a constant sampling effort. Commonly used diversity indices (e.g. richness, Shannon's entropy, Gini-Simpson, Pielou's evenness) as well as a more robust intrinsic diversity-based ordering method were also used as described by Ritt et al. (2011) to evaluate the taxonomic (family) diversity.

\section{$\beta$-diversity}

Despite the modest number of samples, multivariate analyses were conducted to better illustrate the similarities and differences among faunal samples. The lowest available taxonomic level was used (mostly family level) to perform principal component analysis (PCA) and to calculate the Jaccard similarity (Jaccard 1901, Koleff et al. 2003) coefficient as described by Ritt et al. (2010, 2011). A Procrustean randomization test (Jackson 1995, Peres-Neto \& Jackson 2001) was performed to compare the PCA results of the macro- and meiofaunal datasets. Canonical redundancy analyses (RDA) were then performed on macrofaunal abundance data at both MVs with an environmental matrix that included $\mathrm{pH}$, oxygen, methane, sulphate and chloride concentrations at the sediment-water interface, as well as the presence or absence of carbonate concretions. Faunal data were Hellinger-transformed prior to PCA and RDA (Legendre \& Gallagher 2001).

All analyses were performed in the R environment (R Development Core Team 2012). Rarefaction curves, diversity indices and diversity profiles were computed both with the BiodiversityR package (Kindt \& Coe 2005) and functions in Gauthier et al. (2010). Multivariate analyses were carried out using the vegan package (Oksanen et al. 2012).

\section{RESULTS}

\section{Physico-chemical characterisation of microhabitats}

\author{
Sediment appearance
}

Soft sediments sampled at both MVs ranged from muddy to sandy in appearance. The lengths of the blade cores varied from 10 to $21 \mathrm{~cm}$ depending on the nature of the substratum (Table 1). Biv, Plam and Pcc from Napoli and Biv from Amsterdam were characterised by a layer of brown sediments, clearly distinct from the black sediment layer below (Table 2).

\section{Chemical characterisation of the sediment-water} interface

Sulphide concentrations measured at the watersediment interface were lower than the limit of detection $\left(<0.1 \mu \mathrm{mol} \mathrm{l^{-1 }}\right)$ at every microhabitat on Napoli; sulphide was not measured on Amsterdam. Values of $\mathrm{pH}$ in water samples varied from 7.99 to 8.08 on both MVs (Table 2).

Oxygen data at the sediment-water interface were available for both MVs. On Napoli, oxygen varied from $196.4 \mu \mathrm{mol} \mathrm{l}^{-1}$ above CC to $222.5 \mu \mathrm{mol} \mathrm{l}^{-1}$ above Lam, whereas it ranged from $186.8 \mu \mathrm{mol} \mathrm{l}^{-1}$ above Biv to $202.2 \mu \mathrm{mol} \mathrm{^{-1 }}$ above $\mathrm{CC}$ on Amsterdam (Table 2).

The highest methane concentration at Napoli was found in the CC microhabitat, where it peaked at $4.29 \mathrm{~mol} \mathrm{l}^{-1}$, whereas it reached only $0.76 \mu \mathrm{mol} \mathrm{l}^{-1}$ in the soft sediment microhabitat (Lam3; Table 2). In contrast, the highest methane value on the Amsterdam MV was observed over soft sediments, reaching $12.45 \mu \mathrm{mol} \mathrm{l}^{-1}$ above Red1/Red2 and only $0.60 \mu \mathrm{mol}$ $\mathrm{l}^{-1}$ on the $\mathrm{CC}$ microhabitat. The value measured on Red1/Red2 was the highest measured at either MV (Table 2).

Sulphate and chloride concentrations at the sediment-water interface from Napoli and Amsterdam varied from 27.6 to $31.0 \mathrm{mmol} \mathrm{l}^{-1}$ and from 530 to $591 \mathrm{mmol} \mathrm{l}^{-1}$, respectively. The lowest values for both chemicals were observed in the Amsterdam Red microhabitat (Table 2).

No significant differences in $\mathrm{pH}$ or chloride concentrations were detected using Mann-Whitney $U$ tests between the $2 \mathrm{MVs}(W=87, \mathrm{p}>0.05 ; W=115$, $\mathrm{p}=0.19$, respectively), but differences in oxygen, methane and sulphate concentrations were significant $(W=156, \mathrm{p}<0.01 ; W=925, \mathrm{p}<0.05$; and $W=$ $162, \mathrm{p}<0.01$, respectively). 
Table 2. Chemical characteristics of microhabitats on each mud volcano (MV). Visual observations of sediment colour at each microhabitat as well as pH measurements, dissolved oxygen, methane (mean \pm SD, no. of replicates in parentheses), sulphate and chloride concentrations at the sediment-water interface in the replicates of each microhabitat sampled at the Napoli and Amsterdam MVs during the MEDECO cruise (2007). The highest values at each MV are highlighted in bold. Microhabitat codes as in Table $1 ;-$ : not measured

\begin{tabular}{|c|c|c|c|c|c|c|}
\hline Microhabitat & $\begin{array}{l}\text { Visual } \\
\text { observations }\end{array}$ & $\mathrm{pH}$ & $\begin{array}{c}{\left[\mathrm{O}_{2}\right]} \\
\left(\mu \mathrm{mol} \mathrm{l}^{-1}\right)\end{array}$ & $\begin{array}{c}{\left[\mathrm{CH}_{4}\right]} \\
\left.(\mu \mathrm{mol} \mathrm{1}]^{-1}\right)\end{array}$ & $\begin{array}{c}{\left[\mathrm{SO}_{4}{ }^{2-}\right]} \\
\left(\mathrm{mmol} \mathrm{l}^{-1}\right)\end{array}$ & $\begin{array}{c}{\left[\mathrm{Cl}^{-}\right]} \\
\left(\mathrm{mmol} \mathrm{l}^{-1}\right)\end{array}$ \\
\hline \multicolumn{7}{|l|}{ Napoli MV } \\
\hline Biv1 & \multirow[t]{3}{*}{ Brown sediments } & 8.03 & 212.6 & $0.29 \pm 0.00(3)$ & 30.0 & $571^{\mathrm{a}}$ \\
\hline Biv2 & & - & 199.1 & $0.51 \pm 0.03$ & $29.5^{\mathrm{a}}$ & $582^{\mathrm{a}}$ \\
\hline Biv3 & & 8.00 & 215.8 & $0.44 \pm 0.02$ & 30.8 & 585 \\
\hline Lam1 & \multirow{3}{*}{$\begin{array}{l}\text { Black sediments with sulphide } \\
\text { smell }\end{array}$} & 8.02 & 222.5 & $0.35 \pm 0.05(6)$ & 31.0 & 588 \\
\hline Lam2 & & 8.02 & 205.8 & $0.36 \pm 0.05$ & 30.9 & 586 \\
\hline Lam3 & & 7.99 & $212.0^{\mathrm{a}}$ & $0.76 \pm 0.12(4)$ & 30.8 & 584 \\
\hline $\mathrm{CC} 1$ & \multirow{3}{*}{$\begin{array}{l}\text { Dark crusts with cemented fragments } \\
\text { of bivalve shells and tubes }\end{array}$} & 8.00 & 196.4 & $4.29 \pm 2.19$ & $30.8^{\mathrm{a}}$ & 587 \\
\hline $\mathrm{CC} 2$ & & 8.01 & 199.4 & $2.87 \pm 1.22(5)$ & 31.0 & 591 \\
\hline $\mathrm{CC} 3$ & & 8.03 & 196.9 & $2.27 \pm 0.09(7)$ & 30.8 & 585 \\
\hline Plam-A & \multirow[t]{2}{*}{ Brown sediments } & 8.01 & 207.3 & $0.35 \pm 0.06$ & 30.9 & 585 \\
\hline Plam-B & & 8.02 & 221.4 & $0.56 \pm 0.02(2)$ & 30.9 & 584 \\
\hline$P_{C C}-A$ & \multirow[t]{2}{*}{ Brown sediments } & 8.02 & 210.7 & $0.46 \pm 0.06(6)$ & 31.0 & 589 \\
\hline PcC-B & & 8.02 & 199.5 & $0.50 \pm 0.04$ & 30.9 & 587 \\
\hline \multicolumn{7}{|c|}{ Amsterdam MV } \\
\hline Biv1 & \multirow[t]{2}{*}{ Brown sediments } & 8.02 & 195.5 & $0.70 \pm 0.02(5)$ & 30.7 & 586 \\
\hline Biv2 & & 8.02 & 186.8 & $0.41 \pm 0.05$ & 30.8 & 587 \\
\hline Red1/Red2 & \multirow{2}{*}{$\begin{array}{l}\text { Black sediments with sulphide } \\
\text { smell and gas bubbles }\end{array}$} & $8.03^{b}$ & $188.2^{\mathrm{b}}$ & $12.45 \pm 2.10^{b}$ & $27.6^{\mathrm{b}}$ & $530^{\mathrm{b}}$ \\
\hline Red3/Red4 & & $\mathbf{8 . 0 8}^{\mathrm{b}}$ & $191.7^{\mathrm{b}}$ & $2.37 \pm 0.16^{b}(6)$ & $30.7^{b}$ & $585^{\mathrm{b}}$ \\
\hline $\mathrm{CC} 1$ & \multirow{3}{*}{$\begin{array}{l}\text { Grey crusts with cemented frag- } \\
\text { ments of bivalve shells }\end{array}$} & 8.02 & 194.2 & $0.60 \pm 0.04$ & 30.6 & 583 \\
\hline $\mathrm{CC} 2$ & & 8.03 & 198.2 & $0.56 \pm 0.02(2)$ & 30.8 & 588 \\
\hline $\mathrm{CC} 3$ & & 8.02 & 202.2 & $0.25 \pm 0.12(2)$ & 30.6 & 581 \\
\hline
\end{tabular}

Flux measurements

On Napoli, the results obtained on colonised sediments after $14 \mathrm{~h}$ incubation with the benthic chamber CALMAR A above Lamellibrachia anaximandri siboglinids ( $\mathrm{n}>25 \mathrm{ind}$.) indicated an oxygen uptake of $35 \mathrm{mmol} \mathrm{m}^{-2} \mathrm{~d}^{-1}$ and a carbon dioxide flux of $34 \mathrm{mmol}$ $\mathrm{m}^{-2} \mathrm{~d}^{-1}$. A methane flux of $3 \mathrm{mmol} \mathrm{m} \mathrm{m}^{-2} \mathrm{~d}^{-1}$ was also observed. In contrast, under CALMAR B, deployed on peripheral sediments (Plam; no visible fauna), the oxygen uptake was $13.5 \mathrm{mmol} \mathrm{m} \mathrm{m}^{-2} \mathrm{~d}^{-1}$ with a carbon dioxide flux of $11.2 \mathrm{mmol} \mathrm{m}^{-2} \mathrm{~d}^{-1}$. The methane flux never exceeded $0.05 \mathrm{mmol} \mathrm{m}^{-2} \mathrm{~d}^{-1}$.

\section{Distribution of organic matter in sediments}

The percentages of organic carbon in the sediments varied from $0.27 \%$ in the Napoli bivalve microhabitat to over $1.82 \%$ in the Lam microhabitat, where it reached its highest values (Table 3). A similar trend was observed for TN, with concentrations at least 3 times higher in the Lam microhabitats; the lowest values were found in the Napoli Ref site. Similarly, the concentrations of lipids, carbohydrates and amino acids were highest on Lam. On the other hand, the C:N ratio was higher at the Napoli Ref site and lowest in the Lam microhabitats (Table 3). On Amsterdam, the C:N ratio was only slightly higher in the Biv microhabitat compared to the Ref site (Table 3).

Overall, the Lam microhabitat from Napoli was the most enriched in organic matter with a bio-available proportion $>37.7 \%$, which is nearly twice that observed on Biv at both MVs $(23.7 \%$ at Napoli and $26.9 \%$ at Amsterdam; Table 3). In general, most organic compounds decreased with sediment depth $(0$ to $10 \mathrm{~cm})$. The $\mathrm{C}: \mathrm{N}$ ratios in surface sediments varied from 8.6 (Lam 1; Napoli) to 12.7 (Biv1; Amsterdam), with a maximum of 17.5 on the Napoli reference site (Table 3 ). They were relatively constant with depth, with the exception of a sharp decrease in the 1 to $3 \mathrm{~cm}$ slice due to the presence of a black layer of fine sediments enriched in nitrogenous compounds.

The Biv microhabitat from Amsterdam was more enriched in amino acids and lipids, but poorer in carbohydrates than the same microhabitat on Napoli. 
Table 3. Percentage of organic carbon and composition of organic matter (OM) in surface sediments of the different microhabitats from Napoli and Amsterdam mud volcanoes (MVs): total nitrogen (TN), C:N molar ratio, total lipids (lipids), total carbohydrates (CarbH), total hydrolysable amino acids (THAA), proportion of bio-available OM (bio-av. OM) and percentages of carbonates; -: not measured; DW: dry weight. Microhabitat codes as in Table 1

\begin{tabular}{|c|c|c|c|c|c|c|c|c|}
\hline $\begin{array}{l}\text { Micro- } \\
\text { habitat }\end{array}$ & $\begin{array}{c}\text { Organic C } \\
(\% \mathrm{DW})\end{array}$ & $\begin{array}{c}\text { TN } \\
(\% \mathrm{DW})\end{array}$ & $\begin{array}{c}\mathrm{C}: \mathrm{N} \\
\text { (molar) }\end{array}$ & $\begin{array}{l}\text { Lipids } \\
\left(\mathrm{mg} \mathrm{g}^{-1}\right)\end{array}$ & $\begin{array}{c}\text { CarbH } \\
\left(\mathrm{mg} \mathrm{g}^{-1}\right)\end{array}$ & $\begin{array}{l}\text { THAA } \\
\left(\mathrm{mg} \mathrm{g}^{-1}\right)\end{array}$ & $\begin{array}{l}\text { Bio-av. OM } \\
\text { (\% total OM) }\end{array}$ & $\begin{array}{c}\text { Carbonate } \\
\text { (\% DW) }\end{array}$ \\
\hline \multicolumn{9}{|c|}{ Napoli MV } \\
\hline Biv1 & $0.27^{\mathrm{a}}$ & - & - & - & - & - & - & - \\
\hline Biv2 & $0.53^{\mathrm{b}}$ & 0.054 & 11.3 & 0.171 & 1.253 & 0.821 & 23.7 & 29.1 \\
\hline Lam1 & $1.82^{\mathrm{b}}$ & 0.247 & 8.6 & 0.900 & 3.006 & 8.440 & 37.7 & - \\
\hline Lam2 & $1.67^{\mathrm{b}}$ & 0.218 & 9.0 & 0.846 & 3.288 & 8.169 & 40.8 & 24.5 \\
\hline Lam3 & $1.70^{\mathrm{b}}$ & 0.180 & 11.0 & 0.891 & 3.011 & 8.731 & 41.4 & - \\
\hline Plam-A & $0.41^{\mathrm{a}}$ & - & - & - & - & - & - & - \\
\hline Plam-B & $0.82^{\mathrm{a}}$ & - & - & - & - & - & - & - \\
\hline PCC-A & $0.67^{\mathrm{a}}$ & - & - & - & - & - & - & - \\
\hline$P_{C C}-B$ & $0.47^{a}$ & - & - & - & - & - & - & - \\
\hline Ref & $0.57^{\mathrm{b}}$ & 0.038 & 17.5 & - & - & - & - & 47 \\
\hline \multicolumn{9}{|c|}{ Amsterdam MV } \\
\hline Biv1 & $0.60^{\mathrm{b}}$ & 0.055 & 12.7 & 0.219 & 0.846 & 1.848 & 26.9 & 23.3 \\
\hline Ref & $0.62^{\mathrm{b}}$ & 0.066 & 11.0 & - & - & - & - & 39 \\
\hline
\end{tabular}

While the TN was in the same range, the $\mathrm{C}: \mathrm{N}$ ratio and the proportion of bio-available OM were slightly higher on Amsterdam than on Napoli (Table 3). The proportion of carbonates in the sediments was higher on Napoli. Regarding the Ref sites, organic carbon content was low $(<0.65 \%)$ at both MVs, and OM in sediments from the Ref site of Napoli were extremely depleted, with the highest C: $\mathrm{N}$ ratio associated with a low $\mathrm{TN}$ and the highest proportion of carbonates (47\%; Table 3$)$.

\section{Macrofaunal community description}

Overall, a total of 3167 (Biv, Lam, Pcc, Plam; Table 4, and see Tables S4, S5, S7 \& S8 in Supplement 2 at www.int-res.com/articles/suppl/m466 p093_supp.pdf) and 4841 (Red, Biv; Table 4, and see Tables S6 \& S9 in Supplement 2) individuals were sorted in soft sediment microhabitats from Napoli and Amsterdam, respectively (Ref sites excluded). Among these, the proportion of macrofauna sensu stricto was approximately $46 \%$ for both. In the CC microhabitats, a total of 286 and 111 individuals were sorted, with a respective proportion of 65 and $51 \%$ of macrofauna sensu stricto (Table S1 in Supplement 1 and Tables S4 to S9 in Supplement 2). Relative macrofaunal abundances varied between microhabitats and between replicates of the same microhabitat on both MVs.
Abundance, density, composition and $\alpha$-diversity

On Napoli active sites, the mean macrofaunal densities varied from 1607 ind. $\mathrm{m}^{-2}$ on CC to 3733 ind. $\mathrm{m}^{-2}$ in Lam sediments. Densities reached 2925 and 10688 ind. $\mathrm{m}^{-2}$ at the periphery of the Lam patches and CCs, respectively. Density was very low at the Ref site, with 104 ind. $\mathrm{m}^{-2}$ (Table 5). Overall, on Napoli active seep sites (Biv, Lam, CC), the highest macrofaunal densities were found on Lam (Table 5).

On Amsterdam active sites, the mean macrofaunal densities varied from 1222 ind. $\mathrm{m}^{-2}$ in $\mathrm{CC}$ to 24700 ind. $\mathrm{m}^{-2}$ in Red. The density was very low at the Ref site, reaching 232 ind. $\mathrm{m}^{-2}$ (Table 6). Overall, on Amsterdam active seep sites (Biv, Red, CC), the highest macrofaunal density was found in Red (Table 6).

Disregarding the Ref sites, the lowest macrofaunal densities were observed in $\mathrm{CC}$ on both MVs, while the highest was observed in the Red microhabitat on Amsterdam, with a density representing up to 6 times the highest density on Napoli active sites (24 700 versus 3733 ind. $\mathrm{m}^{-2}$ in Lam; Tables 5 \& 6). Macrofaunal densities were much higher within soft sediment microhabitats on Amsterdam than on Napoli (Tables $5 \& 6$ ).

The rarefaction curves on macrofaunal data for each microhabitat on both MVs showed high variability in terms of diversity and adequacy of sampling effort (Fig. 3). The fact that the curves do not level off indicates that, with the exception of 
Table 4. Macrofaunal (>250 $\mu \mathrm{m}$ ) relative abundances $(\%)$ of each taxon in the active microhabitats studied on the Napoli mud volcano (MV): sediments with bivalve shells (Biv, $\mathrm{n}=3$ ), Lamellibrachia (Lam, $\mathrm{n}=3$ ), carbonate crusts $(\mathrm{CC}, \mathrm{n}=3$ ), sediments from the periphery of the Lam microhabitat (Plam, $n=4)$, sediments from the periphery of the CC microhabitat $\left(P_{C C}, n=4\right)$ and reference site (Ref, $\mathrm{n}=1)$; and on the Amsterdam MV: Biv $(\mathrm{n}=2)$, reduced sediments $(\operatorname{Red}, \mathrm{n}=4), \mathrm{CC}(\mathrm{n}=3)$ and $\operatorname{Ref}(\mathrm{n}=1)$ ). Total relative abundances for each taxonomic group are highlighted in bold. ${ }^{*}$ : taxonomic level used for $\alpha$-diversity analyses (mostly family level); ${ }^{* *}$ : values used for $\alpha$-diversity for Plam and Ref only; juv.: juvenile; undet: undetermined. All samples were taken during the MEDECO cruise (2007)

\begin{tabular}{|c|c|c|c|c|c|c|c|c|c|c|}
\hline \multirow{2}{*}{ Taxonomic group } & \multicolumn{6}{|c|}{ - Napoli } & \multicolumn{4}{|c|}{ - Amsterdam } \\
\hline & Biv & Lam & $\mathrm{CC}$ & Plam & Pcc & Ref & Biv & Red & $\mathrm{CC}$ & Ref \\
\hline Porifera (Total) & 8.39 & $\mathbf{0}$ & 27.03 & $\mathbf{0}$ & $\mathbf{0}$ & $\mathbf{0}$ & $\mathbf{0}$ & $\mathbf{0}$ & $\mathbf{0}$ & $\mathbf{0}$ \\
\hline Demospongia*' & 6.99 & 0 & 18.38 & 0 & 0 & 0 & 0 & 0 & 0 & 0 \\
\hline Hexactinellida* & 1.40 & 0 & 8.65 & 0 & 0 & 0 & 0 & 0 & 0 & 0 \\
\hline Cnidaria (Total) & 20.28 & 0.89 & 13.51 & 0.43 & $\mathbf{0}$ & 3.85 & $\mathbf{0}$ & $\mathbf{0}$ & $\mathbf{0}$ & $\mathbf{0}$ \\
\hline \multicolumn{10}{|l|}{ Parazoanthidae $^{*}$} & 0 \\
\hline \multicolumn{11}{|l|}{ Anthozoa - Actiniaria } \\
\hline Sagartiogeton sp. & 0 & 0.45 & 0.54 & 0 & 0 & 0 & 0 & 0 & 0 & 0 \\
\hline Undet. Sargatiidae & 3.50 & 0 & 0 & 0 & 0 & 0 & 0 & 0 & 0 & 0 \\
\hline Undet. Actiniaria* & 0 & 0 & 0 & 0.43 & 0 & 0 & 0 & 0 & 0 & 0 \\
\hline \multicolumn{11}{|l|}{ Medusozoa - Scyphozoa } \\
\hline Polychaeta (Total) & 49.65 & 47.32 & 24.86 & 44.02 & 15.91 & 61.54 & 51.82 & 38.21 & 80.70 & 67.24 \\
\hline Capitellidae $^{*}$ & 0 & 0 & 2.70 & 1.71 & 0 & 7.69 & 5.26 & 0.05 & 0 & 13.79 \\
\hline Chrysopetalidae $^{*}$ & 0 & 0 & 0 & 0 & 0 & 0 & 0 & 0 & 0 & 34.48 \\
\hline Cirratulidae $^{*}$ & 1.40 & 0 & 0 & 15.81 & 0.94 & 7.69 & 16.60 & 0 & 8.77 & 0 \\
\hline Dorvilleidae $^{*}$ & 0.70 & 1.34 & 0.54 & 0.43 & 0.47 & 0 & 4.05 & 23.53 & 0 & 0 \\
\hline Flabelligeridae* & 0 & 0 & 0 & 0 & 0 & 0 & 0 & 0 & 0 & 1.72 \\
\hline Glyceridae* $^{*}$ & 0 & 0 & 0 & 0.85 & 0 & 3.85 & 0.40 & 0 & 0 & 0 \\
\hline Hesionidae $^{*}$ & 0.70 & 7.14 & 0.54 & 0 & 0 & 0 & 0 & 0 & 0 & 3.45 \\
\hline Lumbrineridae $^{*}$ & 0 & 0 & 0 & 0 & 0.35 & 0 & 0.81 & 0 & 0 & 0 \\
\hline Opheliidae $^{*}$ & 0 & 0 & 0 & 0 & 0 & 0 & 0 & 0 & 0 & 5.17 \\
\hline Orbiniidae* & 1.40 & 0 & 0 & 0 & 0 & 7.69 & 0 & 0 & 0 & 0 \\
\hline Paraonidae $^{*}$ & 24.48 & 0 & 0 & 17.09 & 11.00 & 0 & 22.27 & 0.05 & 12.28 & 1.72 \\
\hline Phyllodocidae* & 0 & 5.36 & 2.70 & 0.43 & 0 & 0 & 0.81 & 0 & 0 & 0 \\
\hline Pilargidae $^{*}$ & 0.70 & 0 & 1.62 & 0 & 0 & 0 & 0 & 0 & 0 & 0 \\
\hline Sabellidae* ${ }^{*}$ & 0 & 0 & 0 & 0 & 0 & 0 & 0 & 0 & 0 & 1.72 \\
\hline Scalibregmatidae* & 0 & 0 & 0 & 0 & 0 & 3.85 & 0 & 0 & 0 & 0 \\
\hline Serpulidae $^{*}$ & 0 & 0 & 8.11 & 0 & 0 & 0 & 0 & 0 & 52.63 & 0 \\
\hline \multicolumn{11}{|l|}{ Siboglinidae-Frenulata* } \\
\hline Siboglinum sp. & 11.89 & 0 & 0 & 0.85 & 0.23 & 0 & 0.40 & 0 & 1.75 & 0 \\
\hline \multicolumn{11}{|l|}{ Siboglinidae-Obturata* } \\
\hline Lamellibrachia anaximandri & 0 & 25.00 & 1.08 & 0 & 0 & 0 & 0 & 0 & 0 & 0 \\
\hline Spionidae* ${ }^{*}$ & 1.40 & 1.79 & 2.70 & 0.43 & 2.69 & 19.23 & 1.21 & 4.66 & 5.26 & 0 \\
\hline Syllidae* & 0.70 & 0 & 0 & 0 & 0 & 0 & 0 & 0 & 0 & 0 \\
\hline Terebellida $*$ & 6.29 & 6.70 & 4.32 & 6.41 & 0.23 & 3.85 & 0 & 9.92 & 0 & 5.17 \\
\hline Undet. larvae & 0 & 0 & 0.54 & 0 & 0 & 0 & 0 & 0 & 0 & 0 \\
\hline Undet. Polychaeta & 0 & 0 & 0 & 0 & 0 & 7.69 & 0 & 0 & 0 & 0 \\
\hline Bivalvia (Total) & 0.70 & 0.89 & 2.70 & 18.38 & 2.92 & $\mathbf{0}$ & 9.31 & 61.29 & 3.51 & $\mathbf{0}$ \\
\hline \multicolumn{11}{|l|}{ Lucinidae* $^{*}$} \\
\hline Myrtea amorpha & 0 & 0 & 0 & 2.56 & 0 & 0 & 0 & 0 & 0 & 0 \\
\hline Lucinoma kazani & 0 & 0 & 0 & 0 & 0 & 0 & 0.40 & 0 & 0 & 0 \\
\hline Undet. Lucinidae & 0 & 0 & 0 & 1.28 & 0 & & & & & \\
\hline \multicolumn{11}{|l|}{ Thyasiridae* $^{*}$} \\
\hline Thyasiria striata & 0 & 0 & 0 & 0 & 0.58 & 1.62 & 0.15 & 1.75 & 1.75 & 0 \\
\hline Axinulus croulinensis & 0 & 0 & 0 & 3.85 & 0.12 & 0 & 0 & 0 & 0 & 0 \\
\hline Undet. Thyasiridae & 0 & 0 & 0 & 8.55 & 0.58 & 0 & 0 & 0 & 0 & 0 \\
\hline \multicolumn{11}{|l|}{ Vesicomyidae* } \\
\hline Isorropodon perplexum & 0 & 0 & 0 & 0 & 0 & 0 & 0 & 0.05 & 0 & 0 \\
\hline Undet. Vesicomyidae & 0 & 0 & 0 & 0 & 0 & 0 & 4.86 & 61.03 & 1.75 & 0 \\
\hline
\end{tabular}


Table 4 (continued)

\begin{tabular}{|c|c|c|c|c|c|c|c|c|c|c|}
\hline \multirow{2}{*}{ Taxonomic group } & \multirow[b]{2}{*}{ Biv } & \multirow[b]{2}{*}{ Lam } & \multirow{2}{*}{$-\mathrm{Na}$} & \multirow{2}{*}{ poli } & \multirow[b]{2}{*}{ PcC } & \multirow[b]{2}{*}{ Ref } & \multirow[b]{2}{*}{ Biv } & \multicolumn{2}{|c|}{ - Amsterdam } & \multirow[b]{2}{*}{ Ref } \\
\hline & & & & & & & & Red & $\mathrm{CC}$ & \\
\hline \multicolumn{11}{|l|}{ Mytilidae* } \\
\hline Idas aff. modiolaeformis & 0.70 & 0.89 & 1.08 & 0 & 0 & 0 & 0 & 0 & 0 & 0 \\
\hline Undet. Bivalvia & 0 & 0 & 1.62 & 2.14 & 1.64 & 0 & 2.43 & 0.05 & 0 & 0 \\
\hline Gastropoda (Total) & 11.19 & 5.36 & 22.70 & 0.43 & $\mathbf{0}$ & $\mathbf{0}$ & 0.40 & $\mathbf{0}$ & 12.28 & 24.14 \\
\hline \multicolumn{11}{|l|}{ Calliotropidae $^{*}$} \\
\hline \multicolumn{2}{|l|}{ Orbitestellidae* } & & 3.24 & 0 & 0 & 0 & 0 & 0 & 0 & 0 \\
\hline Lurifax vitreus & 4.90 & 0 & 12.43 & 0 & 0 & 0 & 0.40 & 0 & 10.53 & 0 \\
\hline \multicolumn{11}{|l|}{ Skeneidae* } \\
\hline Undet. Skeneidae & 0 & 3.57 & 0 & 0 & 0 & 0 & 0 & 0 & 0 & 0 \\
\hline \multicolumn{11}{|l|}{ Conidae* ${ }^{*}$} \\
\hline $\begin{array}{l}\text { Taranis moerchi } \\
\text { Cocculinidae }^{*}\end{array}$ & \multicolumn{9}{|c|}{ Cocculinidae* $^{*}$} & 0 \\
\hline $\begin{array}{l}\text { Coccopigya sp. } \\
\text { Cuspidariidae** }\end{array}$ & \multicolumn{9}{|c|}{ Cuspidariidae** } & 0 \\
\hline Cuspidaria sp. & 1.40 & 0 & 0 & 0 & 0 & 0 & 0 & 0 & 0 & 0 \\
\hline Undet. Gastropoda ${ }^{* *}$ & 2.80 & 1.79 & 4.86 & $0.43^{* *}$ & 0 & 0 & 0 & 0 & 1.75 & $24.14^{* *}$ \\
\hline Aplacophora (Total) & $\mathbf{0}$ & $\mathbf{0}$ & $\mathbf{0}$ & 0.85 & 0.12 & 7.69 & 2.83 & $\mathbf{0}$ & $\mathbf{0}$ & $\mathbf{0}$ \\
\hline \multicolumn{11}{|l|}{ Chaetodermatidae* } \\
\hline Polyplacophora (Total) & 0 & 0 & 0 & 0 & 0 & 0 & $\begin{array}{c}2.00 \\
0\end{array}$ & 0 & 0 & 3.45 \\
\hline Undet. Polyplacophora* & 0 & 0 & 0 & 0 & 0 & 0 & 0 & 0 & 0 & 3.45 \\
\hline Sipuncula (Total) & 1.40 & $\mathbf{0}$ & 2.16 & 0.85 & $\mathbf{0}$ & 11.54 & 0.40 & $\mathbf{0}$ & $\mathbf{0}$ & $\mathbf{0}$ \\
\hline \multicolumn{11}{|l|}{ Phascolosomatidae* } \\
\hline Apionsoma murina & 1.40 & 0 & 0 & 0.85 & 0 & 0 & & & & \\
\hline Phascolosoma aff. granulatum & 0 & 0 & 0 & 0 & 0 & 0 & 0.40 & 0 & 0 & 0 \\
\hline Golfingiidae* $^{*}$ & & & & & & & & & & \\
\hline Nephasoma sp. juv. & 0 & 0 & 0.54 & 0 & 0 & 0 & 0 & 0 & 0 & 0 \\
\hline Nephasoma liljeborgi & 0 & 0 & 1.62 & 0 & 0 & 0 & 0 & 0 & 0 & 0 \\
\hline Undet. Sipuncula* & 0 & 0 & 0 & 0 & 0 & 11.54 & 0 & 0 & 0 & 0 \\
\hline Echiuria (Total) & 0.70 & $\mathbf{0}$ & $\mathbf{0}$ & $\mathbf{0}$ & $\mathbf{0}$ & $\mathbf{0}$ & $\mathbf{0}$ & $\mathbf{0}$ & $\mathbf{0}$ & $\mathbf{0}$ \\
\hline Echiuridae $^{*}$ & & & & & & & & & & \\
\hline Echiurus abyssalis & 0.70 & 0 & 0 & 0 & 0 & 0 & 0 & 0 & 0 & 0 \\
\hline Nemerta (Total) & $\mathbf{0}$ & $\mathbf{0}$ & $\mathbf{0}$ & $\mathbf{0}$ & $\mathbf{0}$ & 7.69 & $\mathbf{0}$ & $\mathbf{0}$ & $\mathbf{0}$ & 3.45 \\
\hline Undet. Nemerta ${ }^{*}$ & 0 & 0 & 0 & 0 & 0 & 7.69 & 0 & 0 & 0 & 3.45 \\
\hline Crustacea (Total) & 7.69 & 45.54 & 7.03 & 35.04 & 81.05 & 7.69 & 35.22 & 0.51 & 3.51 & $\mathbf{0}$ \\
\hline $\begin{array}{l}\text { Amphipoda-Gammaridae } \\
\text { Sebidae* }^{*}\end{array}$ & & & & & & & & & & \\
\hline $\begin{array}{l}\text { Seba sp. } \\
\text { Lysianasidae* }\end{array}$ & 0 & 0 & 1.62 & 0 & 0 & 0 & 0 & 0 & 0 & 0 \\
\hline $\begin{array}{l}\text { Orchomene grimaldii } \\
\text { Calliopiidae* }\end{array}$ & 0 & 5.80 & 0 & 0 & 0 & 0 & 0 & 0 & 0 & 0 \\
\hline $\begin{array}{l}\text { Bouvierella carcinophila } \\
\text { Oedicerotidae* }\end{array}$ & 0 & 23.66 & 0 & 0.85 & 0.23 & 0 & 0 & 0 & 0 & 0 \\
\hline Monoculodes sp. & 0 & 0 & 0 & 1.28 & 0.12 & 0 & 1.21 & 0 & 0 & 0 \\
\hline Oedicerotidae gen. sp. & 0 & 0 & 0 & 0.43 & 0 & 0 & & & & \\
\hline Periculodes aff. longimanus & 0 & 0 & 0 & 0.85 & 0 & 0 & 0 & 0.25 & 0 & 0 \\
\hline Phoxocephalidae* & & & & & & & & & & \\
\hline Harpiniopsis sp. & 0 & 0 & 0 & 0 & 0 & 0 & 0.40 & 0 & 1.75 & 0 \\
\hline Stegocephalidae* ${ }^{*}$ & & & & & & & & & & \\
\hline Stegocephaloides christianiensis & 0 & 0 & 1.62 & 0 & 0 & 0 & 0 & 0 & 0 & 0 \\
\hline Undet. Gammaridae & 0 & 6.70 & 0 & 0 & 0 & 0 & 0.40 & 0 & 0 & 0 \\
\hline $\begin{array}{l}\text { Cumacea } \\
\text { Diastyloidae* }\end{array}$ & & & & & & & & & & \\
\hline Diastyloides serrata & 2.80 & 0 & 0 & 6.84 & 0 & 0 & 0 & 0 & 0 & 0 \\
\hline Diastylis sp. & 0 & 0 & 0 & 0 & 0.35 & 0 & 0 & 0.15 & 0 & 0 \\
\hline
\end{tabular}


Table 4 (continued)

\begin{tabular}{|c|c|c|c|c|c|c|c|c|c|c|}
\hline \multirow[t]{2}{*}{ Taxonomic group } & \multirow[b]{2}{*}{ Biv } & \multirow[b]{2}{*}{ Lam } & \multicolumn{2}{|c|}{ - Napoli } & \multirow[b]{2}{*}{ PcC } & \multirow[b]{2}{*}{ Ref } & \multirow[b]{2}{*}{ Biv } & \multicolumn{2}{|c|}{ - Amsterdam } & \multirow[b]{2}{*}{ Ref } \\
\hline & & & $\mathrm{CC}$ & Plam & & & & Red & $\mathrm{CC}$ & \\
\hline \multicolumn{11}{|l|}{ Isopoda-Asellota } \\
\hline \multicolumn{11}{|l|}{ Munnopsidae* } \\
\hline Disconectes sp. 1 & 0.70 & 0 & 0 & 0 & 0.12 & 0 & 2.02 & 0 & 0 & 0 \\
\hline Disconectes sp. 2 & 0.70 & 0 & 0 & 0 & 0 & 0 & 0 & 0 & 0 & 0 \\
\hline Ilyarachna sp. 1 & 0 & 0 & 0 & 0 & 0.23 & 0 & 1.62 & 0 & 0 & 0 \\
\hline Ilyarachna sp. 2 & 0 & 0 & 0 & 0 & 0 & 0 & 0 & 0.05 & 0 & 0 \\
\hline Ilyarachna sp. juv. & 0 & 0 & 0 & 0 & 0.12 & 0 & 0 & 0 & 0 & 0 \\
\hline Undet. Ilyarachna sp. & 0 & 0 & 0 & 0 & 0.12 & 0 & 0 & 0 & 0 & 0 \\
\hline \multicolumn{11}{|l|}{ Desmosomatidae* } \\
\hline Chelatorsp. & 0 & 0 & 1.62 & 0 & 7.37 & 0 & 0 & 0 & 0 & 0 \\
\hline Eugerda sp. 1 & 0 & 0 & 0.54 & 10.26 & 4.68 & 0 & 1.21 & 0 & 0 & 0 \\
\hline Eugerda sp. 2 & 0 & 0 & 0 & 2.99 & 1.05 & 0 & 4.45 & 0 & 0 & 0 \\
\hline Eugerda sp. 3 & 0 & 0 & 0 & 0 & 0.12 & 0 & 0 & 0 & 0 & 0 \\
\hline Eugerda filipes & 0 & 0 & 0 & 0.43 & 0.12 & 0 & 0 & 0 & 0 & 0 \\
\hline Undet. Eugerda sp. & 0 & 0 & 0 & 0.43 & 0.23 & 0 & 0 & 0 & 0 & 0 \\
\hline Eugerda sp. juv. & 0 & 0 & 0 & 0 & 0 & 0 & 0.40 & 0 & 0 & 0 \\
\hline Pseudogerda atypicum & 0 & 0 & 0 & 0 & 0 & 0 & 1.62 & 0 & 0 & 0 \\
\hline Whoia sp. & 0 & 0 & 0 & 0 & 0.12 & 0 & 0 & 0 & 0 & 0 \\
\hline Desmosoma aff. tyrrhencium & 0 & 0 & 0 & 2.99 & 0 & 0 & 0 & 0 & 0 & 0 \\
\hline Desmosoma aff. elegans & 0 & 0 & 0 & 0 & 0.35 & 0 & 0 & 0 & 0 & 0 \\
\hline Desmosoma elegans & 0 & 0 & 0 & 1.28 & 0 & 0 & 0 & 0 & 0 & 0 \\
\hline Desmosomatidae juv. & 0 & 0 & 0 & 0 & 0.12 & 0 & 0 & 0 & 0 & 0 \\
\hline Undet. Desmosomatidae & 0 & 0 & 0.54 & 0 & 0 & 0 & 0 & 0 & 0 & 0 \\
\hline \multicolumn{11}{|l|}{ Isopoda-Epicaridae } \\
\hline Undet. Epicaridae* & 0 & 0.45 & 0 & 0 & 0 & 0 & 0 & 0 & 0 & 0 \\
\hline Undet. Isopoda & 0 & 0 & 0 & 0 & 0 & 0 & 1.21 & 0 & 0 & 0 \\
\hline \multicolumn{11}{|l|}{ Leptostraca } \\
\hline Undet. Leptostraca* & 0 & 8.93 & 0 & 0 & 0 & 0 & 0 & 0 & 0 & 0 \\
\hline \multicolumn{11}{|l|}{ Tanaidacea } \\
\hline \multicolumn{11}{|l|}{ Pseudotanaidae* } \\
\hline Pseudotanais sp. & 0 & 0 & 0 & 3.85 & 0.12 & 0 & 0.40 & 0 & 0 & 0 \\
\hline Agathotanaidae* & 0 & 0 & 0 & 1.28 & 65.49 & 0 & 18.22 & 0 & 0 & 0 \\
\hline Anarthruridae* & 0 & 0 & 0 & 0.43 & 0 & 0 & 0 & 0 & 0 & 0 \\
\hline Paragnathotanaidae* & 0.70 & 0 & 0 & 0.85 & 0 & 0 & 0.40 & 0 & 0 & 0 \\
\hline \multicolumn{11}{|l|}{ Leptognathiellidae* } \\
\hline Leptognathiellidae sp. 1 & 2.10 & 0 & 1.08 & 0 & 0 & 0 & 0.81 & 0 & 0 & 0 \\
\hline Leptognathiellidae sp. 2 & 0.70 & 0 & 0 & 0 & 0 & 0 & 0 & 0 & 1.75 & 0 \\
\hline \multicolumn{11}{|l|}{ Tanallidae $^{*}$} \\
\hline Tanaella sp. & 0 & 0 & 0 & 0 & 0 & 0 & 0.40 & 0 & 0 & 0 \\
\hline Undet. Tanaidacea ${ }^{* *}$ & 0 & 0 & 0 & 0 & 0 & $7.69^{* *}$ & 0.40 & 0 & 0 & 0 \\
\hline \multicolumn{11}{|l|}{ Decapoda } \\
\hline Undet. Decapoda* & 0 & 0 & 0 & 0 & 0 & 0 & 0 & 0.05 & 0 & 0 \\
\hline Echinodermata (Total) & $\mathbf{0}$ & $\mathbf{0}$ & $\mathbf{0}$ & $\mathbf{0}$ & $\mathbf{0}$ & $\mathbf{0}$ & $\mathbf{0}$ & $\mathbf{0}$ & $\mathbf{0}$ & 1.72 \\
\hline Undet. Echinoida* & 0 & 0 & 0 & 0 & 0 & 0 & 0 & 0 & 0 & 1.72 \\
\hline Total abundance (no. of ind.) & 143 & 224 & 185 & 234 & 855 & 26 & 247 & 1976 & 57 & 58 \\
\hline
\end{tabular}

Pcc, most Napoli microhabitats were under-sampled (Fig. 3a). Nonetheless, the Biv microhabitat appeared to have the richest, and the PCC habitat the poorest communities sampled on Napoli (Fig. 3a, Table 5). It should be noted that additional sampling could change the ranking of the curves (Fig. 3a). Most communities, and in particular the Ref and CC microhabitats, had high evenness, while the periphery of the CC was notably uneven $\left(J^{\prime}\right.$; Table 5). Moreover, the CC microhabitat was almost 4.5 times more diverse than its periphery $\left(\operatorname{Exp}\left[H_{\mathrm{e}}{ }^{\prime}\right]\right.$; Table 5$)$.

On Amsterdam, and because of the high density, Red was the only habitat that showed a leveled-off curve (Fig. 3b). The curves and the low numbers of captured individuals for Biv, CC and Ref indicate that these microhabitats were under-sampled, especially the CC microhabitat that had the lowest observed taxonomic richness $\left(S_{\text {obs }}\right)$. The observed macrofaunal 
Table 5. Biological descriptors of the studied microhabitats for the Napoli mud volcano sampled in the Mediterranean Sea. The observed taxonomic richness is given at the family level. The number equivalents of the Shannon and Simpson indices are given in italics. The highest values are highlighted in bold. $\mathrm{n}=3$ for all microhabitats + periphery, except for the reference site where $\mathrm{n}=1$. ES50: expected richness for a sample of 50 individuals; $S_{\text {obs: }}$ observed taxonomic richness; - : not measured. Microhabitat codes as in Table 1

\begin{tabular}{|c|c|c|c|c|c|c|}
\hline \multirow[t]{2}{*}{ Biological descriptor } & \multirow[t]{2}{*}{ Bivalve shells } & \multirow[t]{2}{*}{ Lamellibrachia } & \multirow{2}{*}{$\begin{array}{l}\text { Carbonate } \\
\text { crusts }\end{array}$} & \multicolumn{2}{|c|}{ Periphery } & \multirow{2}{*}{$\begin{array}{l}\text { Reference } \\
\text { site }\end{array}$} \\
\hline & & & & Plam & PCC & \\
\hline $\begin{array}{l}\text { Mean }( \pm \mathrm{SD}) \text { macrofaunal } \\
\text { densities (ind. } \mathrm{m}^{-2} \text { ) }\end{array}$ & $2383 \pm 289$ & $3733 \pm 3523$ & $1619 \pm 1147$ & $2925 \pm 1577$ & $10688 \pm 12825$ & 104 \\
\hline Mean Jaccard's similarity & 0.39 & 0.36 & 0.38 & 0.33 & 0.27 & - \\
\hline $\begin{array}{l}\text { Symbiont-bearing } \\
\text { fauna }(\%)\end{array}$ & $7.8-17.7$ & $14.2-75.0$ & $0-3.7$ & $1-6.3$ & $0-3.5$ & 0 \\
\hline $\begin{array}{l}\text { Total biomass } \\
\text { (kg preserved } \\
\text { wet weight } \mathrm{m}^{-2} \text { ) }\end{array}$ & $0.0033 \pm 0.004$ & $4.73 \pm 1.05$ & $0.019 \pm 0.03$ & $0.0005 \pm 0.0007$ & $0.00032 \pm 0.0003$ & - \\
\hline Richness $\left(S_{\text {obs }}\right)$ & 25 & 14 & 24 & 22 & 17 & 12 \\
\hline ES50 & 16 & 10 & 17 & 13 & 6 & 12 \\
\hline Shannon $\left(H_{\mathrm{e}}\right)$ & 2.52 & 2.11 & 2.70 & 2.40 & 1.18 & 2.36 \\
\hline $\operatorname{Exp}\left(H_{\mathrm{e}}\right)$ & 12.43 & 7.77 & 14.88 & 11.02 & 3.25 & 10.59 \\
\hline Simpson $\left(D_{\mathrm{GS}}\right)$ & 0.87 & 0.83 & 0.91 & 0.88 & 0.53 & 0.89 \\
\hline $1 /\left(1-D_{\mathrm{GS}}\right)$ & 7.99 & 5.81 & 10.65 & 8.24 & 2.11 & 9.29 \\
\hline Evenness $(J)$ & 0.78 & 0.78 & 0.85 & 0.78 & 0.42 & 0.95 \\
\hline
\end{tabular}

Table 6. Biological descriptors of the studied microhabitats for the Amsterdam mud volcano sampled in the Mediterranean Sea. The observed taxonomic richness is given at the family level. The number equivalents of the Shannon and Simpson indices are given in italics. Only the large meiofauna $>250 \mu \mathrm{m}$ was considered in this study. The highest values are highlighted in bold. $\mathrm{n}=2$ for the bivalve shell microhabitat, $\mathrm{n}=4$ for the reduced sediments, $\mathrm{n}=3$ for the carbonate crusts and $\mathrm{n}=1$ for the reference site. ES50: expected richness for a sample of 50 individuals; $S_{\text {obs: }}$ observed taxonomic richness; -: not measured

\begin{tabular}{|c|c|c|c|c|}
\hline Biological descriptor & Bivalve shells & Reduced sediments & Carbonate crusts & Reference site \\
\hline $\begin{array}{l}\text { Mean }( \pm \mathrm{SD}) \text { macrofaunal } \\
\text { densities (ind. } \mathrm{m}^{-2} \text { ) }\end{array}$ & $6175 \pm 3712$ & $24700 \pm 7477$ & $1222 \pm 727$ & 232 \\
\hline Mean Jaccard's similarity & 0.43 & 0.55 & 0.48 & - \\
\hline Symbiont-bearing fauna (\%) & $2.8-9.0$ & 41.7-77.2 & $0-9.1$ & 0 \\
\hline $\begin{array}{l}\text { Total biomass (kg preserved } \\
\text { wet weight } \mathrm{m}^{-2} \text { ) }\end{array}$ & $0.021 \pm 0.02$ & $0.049 \pm 0.02$ & $0.0012 \pm 0.002$ & - \\
\hline Richness $\left(S_{\text {obs }}\right)$ & 25 & 11 & 10 & 12 \\
\hline ES50 & 13 & 4 & 9 & 11 \\
\hline Shannon $\left(H_{\mathrm{e}}\right)$ & 2.36 & 1.06 & 1.57 & 1.92 \\
\hline $\operatorname{Exp}\left(H_{\mathrm{e}}\right)$ & 10.70 & 2.89 & 4.81 & 6.82 \\
\hline Simpson $\left(D_{\mathrm{GS}}\right)$ & 0.86 & 0.56 & 0.67 & 0.79 \\
\hline $1 /\left(1-D_{\mathrm{GS}}\right)$ & 7.28 & 2.27 & 3.06 & 4.85 \\
\hline Evenness $(J)$ & 0.73 & 0.44 & 0.68 & 0.77 \\
\hline
\end{tabular}

family richness $\left(S_{\text {obs }}\right)$ in Red, CC and Ref was between 10 and 12, although it reached 25 in the Biv microhabitat, but ES50 in Red was much lower (13; Table 6) and additional samples should confirm this ranking (Fig. 3b). As on Napoli, the highest richness was observed in the Biv microhabitat (Fig. 3b). The evenness $(J)$ was higher at Ref and in Biv and lowest in Red. The Shannon and Simpson indices gave the exact same ranking: they were highest in Biv, intermediate in Ref and CC and lowest in Red (Biv> Ref $>$ CC $>$ Red; Table 6), and according to the number equivalents of the Shannon index, Biv was al- most 4 times more diverse than Red (Table 6). At both MVs, the evenness was higher at the Ref sites (Tables 5 \& 6).

To compare the $2 \mathrm{MVs}$ (Napoli and Amsterdam), we pooled the data from all microhabitat samples (Ref sites excluded). The sample-based rarefaction curves on macrofaunal data from pooled microhabitats clearly showed that the active sites of Napoli exhibited the highest diversity while the picture was less clear for the peripheral sites and Amsterdam active sites (Fig. 4a). The curves for the Amsterdam active sites and the peripheral sites on Napoli pro- 

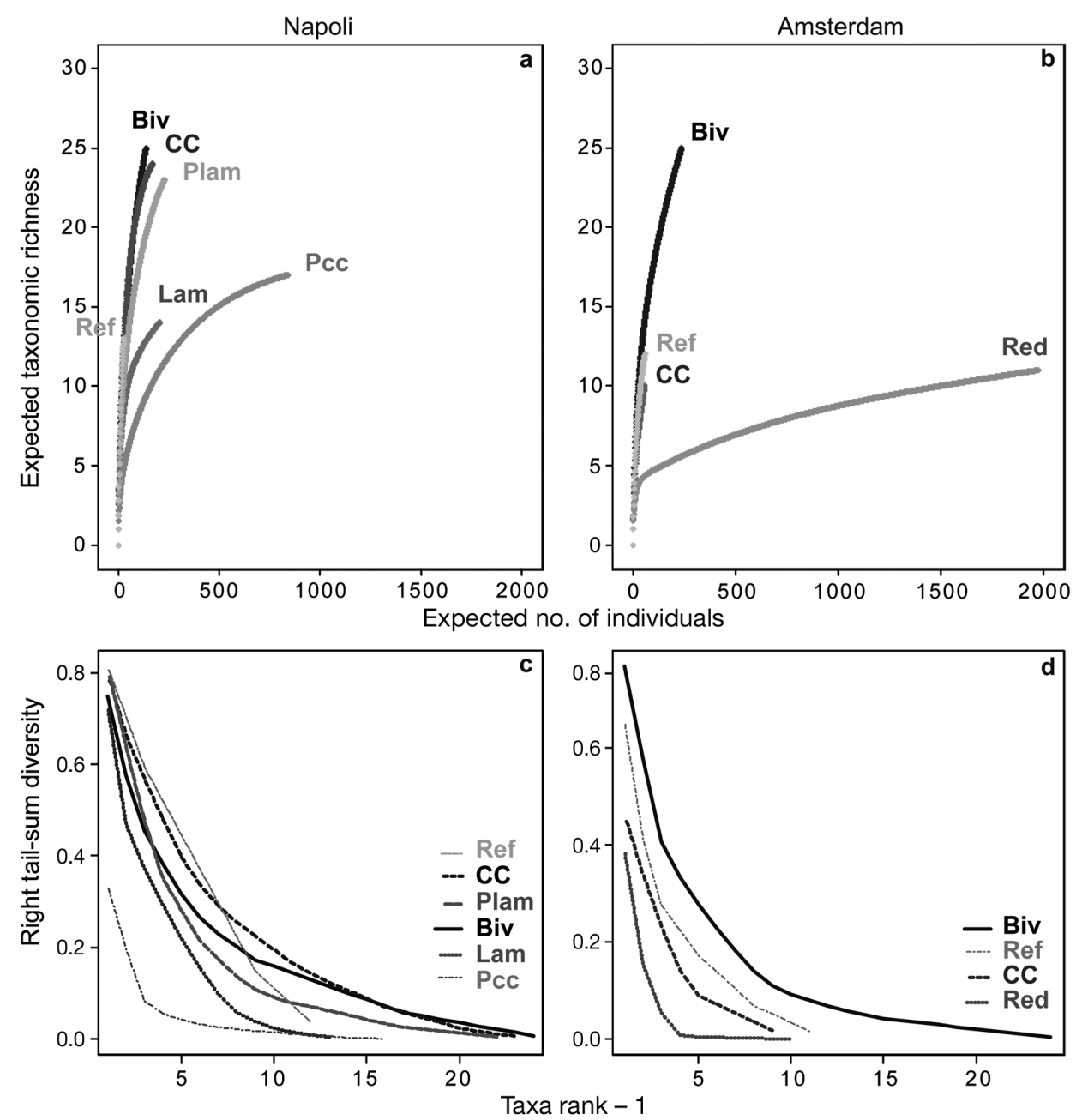

Fig. 3. $(\mathrm{a}, \mathrm{b})$ Rarefaction curves and $(\mathrm{c}, \mathrm{d})$ the right tail-sum (RTS) intrinsic diversity profiles performed with macrofaunal abundances at the family level, for all the microhabitats, including the reference sites, sampled on the $(a, c)$ Napoli and $(b, d)$ Amsterdam mud volcanoes

vide a relatively good picture of their macrofaunal taxonomic richness, but it is unclear which of the 2 harbours higher taxonomic richness (Fig. 4a). Despite a lower sampling effort (9 versus 17 sampling units), higher macrofaunal densities led to more individuals observed on Amsterdam than on Napoli.

Of the taxa present, different morphologies may be distinguished among Demospongia, Terebellida, Leptostraca and Nematoda, whereas a single morphology was observed for Hexactinellida, Scyphozoa, Polyplacophora, Nemerta and Echinoida, suggesting the presence of a single family for these taxa. On Napoli, Biv was dominated by Paraonidae polychaetes $(24.5 \%$ of the total abundance; Table 4$)$, Demospongia $(\sim 7 \%)$ and Orbitestilidae gastropods $(4.9 \%)$. The Obturata polychaetes dominated in Lam microhabitat $(25 \%)$, while CC was dominated by Porifera ( $27 \%$; Table 4). Macrofaunal communities at the periphery of Lam and CC were mainly represented by Paraonidae polychaetes $(17.1 \%)$ and Agathotanaidae (65.5\%; Table 4). The Napoli Ref site was dominated by Spionidae polychaetes $(19.2 \%)$ and several other families in equal proportion $(7.7 \%$; Table 4). It is interesting to note that most polychaete families observed in Biv were absent in Lam and vice versa. Indeed, the 2 siboglinid species never cooccurred in a given microhabitat (Table 4). For the peripheral samples, replicates showed higher heterogeneity between replicates taken close to the active sites (Plam-A and PcC-A) than between those taken farther away (Plam-B and Pcc-B; Table 4). Overall, most of the families were common (8) to both active and peripheral sites from Napoli (Table 4). Five families were common to both active sites and the Ref site, and a single family was exclusively observed at the latter (Scalibregmatidae; Table 4). 

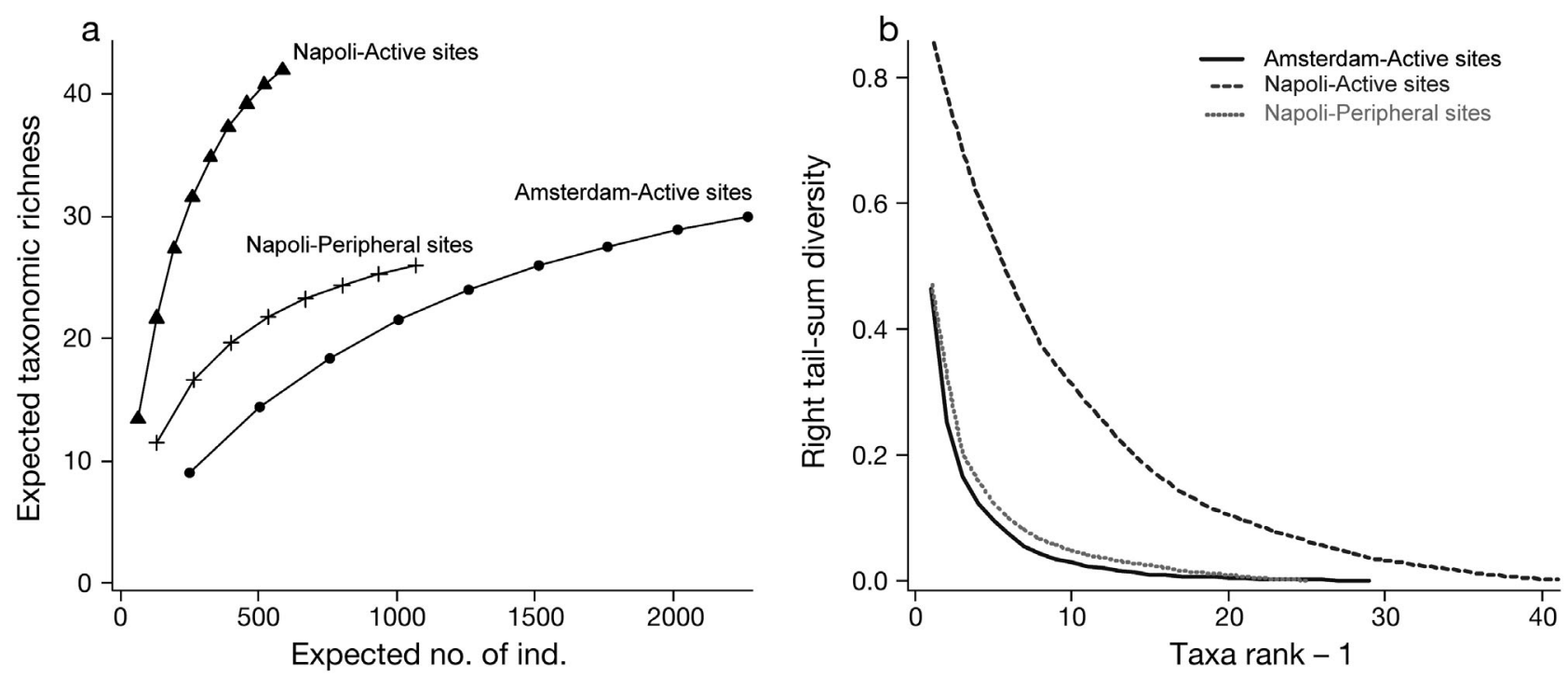

Fig. 4. (a) Rarefaction curves and (b) the right tail-sum (RTS) intrinsic diversity profiles performed on macrofaunal abundances at the family level on the Napoli and Amsterdam mud volcanoes (MVs). Data from the active sites as well as the peripheral sites were pooled. The reference sites at each MV were not included. Overall, Napoli, $\mathrm{n}=17 ;$ Amsterdam, $\mathrm{n}=9$

On Amsterdam, Paraonidae polychaetes dominated Biv $(22.3 \%$ of the total abundance; Table 4$)$, while Serpulidae represented $52.6 \%$ of the total macrofauna in CC. Red was dominated by undetermined Vesicomyidae bivalves with a proportion close to $61.3 \%$ (Table 4), while Chrysopetalidae polychaetes dominated the Ref site $(51.8 \%$, Table 4$)$. Similar to what was observed on Napoli, the 2 siboglinid species appeared to segregate according to microhabitat, with Siboglinum sp. being present exclusively in the Biv microhabitat and Lamellibrachia anaximandri only in CC (Table 4). Interestingly, 5 of the 8 polychaete families present at the Ref site were not observed at any of the active sites (Table 4).

When comparing the $2 \mathrm{MVs}$, it can be noted that poriferans and cnidarians were exclusively observed on Napoli, gastropods had higher occurrences on Napoli, and bivalves were more represented on Amsterdam. The microhabitats Lam on Napoli and Red on Amsterdam were both characterised by the presence of reduced sediments from the surface to the deeper layers, by low oxygen penetration in Lam and one of the lowest oxygen concentrations in Biv, and by the presence of dorvilleid and terebellid polychaetes (Table 4).

The right-tail sum intrinsic diversity profiles for the pooled samples confirmed that Napoli had the highest $\alpha$-diversity (Fig. $4 \mathrm{~b}$ ). On the Amsterdam MV, the most abundant taxa represented $50 \%$ of the total macrofaunal abundance, but only $10 \%$ on Napoli (Fig. 4b). Assuming homogenous spatial distributions on each MV and that all available microhabitats were sampled, additional sampling would probably not change the diversity ordering of these MVs. However, we know that all microhabitats were not sampled and that seep communities tend to have heterogeneous spatial distributions; it is thus likely that our estimates do not give a complete picture of the diversity of these $2 \mathrm{MVs}$.

\section{Macrofaunal biomass}

The highest biomass was observed on Napoli, in the Lam microhabitat (up to $4 \mathrm{~kg}$ wet weight [ww] $\mathrm{m}^{-2}$; Table 5) due to the presence of long (up to $1 \mathrm{~m}$ ) Siboglinidae polychaetes. In the other Napoli microhabitats, biomass was low, not exceeding $0.019 \mathrm{~kg}$ ww $\mathrm{m}^{-2}$ (Table 5). On Amsterdam, the mean biomass was more homogeneous throughout the microhabitats, ranging from 0.0012 to $0.049 \mathrm{~kg} \mathrm{ww} \mathrm{m^{-2 }}$ (Table 6). Apart from the high values observed in the Napoli Lam microhabitat, the mean biomasses observed in the Amsterdam MV microhabitats were generally higher than those observed on Napoli. The vertical distribution of the biomass is presented in Section 2 and Fig. S2 of Supplement 1.

Symbiont-bearing fauna versus heterotrophic fauna

The symbiont-bearing fauna (SBF) represented from 0 to $77 \%$ of the total macrofaunal abundance sampled on the 2 MVs (Tables $5 \& 6$; Fig. 5). The SBF observed 


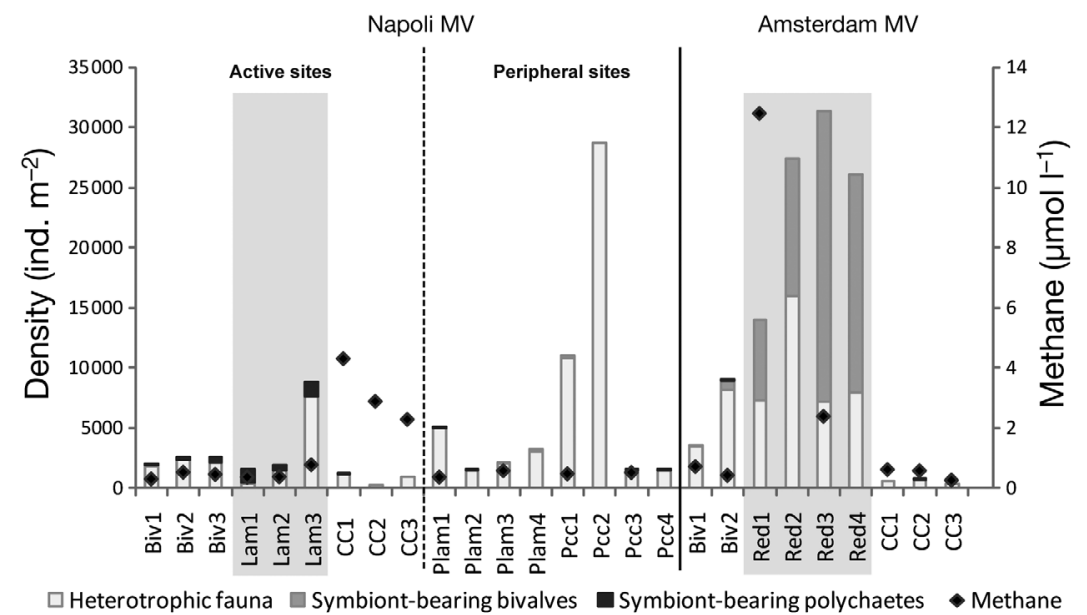

Fig. 5. Density (ind. $\mathrm{m}^{-2}$ ) of symbiont-bearing and heterotrophic macrofauna in each replicate of the microhabitats sampled on the Napoli and Amsterdam mud volcanoes (MVs). Biv: sediments with bivalve shells; Lam: Lamellibrachia; CC: carbonate crust; Plam: periphery of the Lam; PCC: periphery of the CC. Methane concentrations (black diamonds) for each replicate are given. Reduced microhabitats are shaded in grey (Lam and Red)

not be ruled out that these differences are attributable to the sampling strategy; thus we decided to focus on macrofauna sensu stricto thereafter.

On Napoli, mean Jaccard's similarities for macrofauna were systematically lower than $40 \%$ within the same microhabitats (Table 6), implying a certain degree of heterogeneity at the microhabitat scale. PCA and clustering of macrofaunal abundance data allowed the distinction of 3 groups: Biv and CC microhabitats; Plam and Pcc microhabitats; and the Lam microhabitat. Overall, variability was lower within than among microhabitats (Fig. 6a). Of the taxa that contributed to the dispersion of samples in the PCA, Demospongia, Orbitestillidae and Scyphozoa were more abundant in Biv and CC, Obturata in Lam, and

in the microhabitats sampled on Napoli was dominated by siboglinid polychaetes, whereas on Amsterdam, it was dominated by various bivalve families, especially Vesicomyidae (Table 4). On Napoli, Siboglinidae were represented by 2 main groups: the vestimentiferans or obturates (Lamellibrachia anaximandri) that were exclusively observed in the Lam microhabitat and the frenulates (Siboglinum sp.), that were exclusively found in the Biv microhabitat (Table 4). Live L. anaximandri were observed on Amsterdam, often associated with CCs, but were not sampled (Table 4).

On both MVs, the CC microhabitat exhibited the lowest proportion of SBF (up to $3.7 \%$ on Napoli and up to $9.1 \%$ on Amsterdam; Tables 5 \& 6), with only two-thirds of the samples containing SBF. Densities of SBF were higher in Lam on Napoli and in Red on Amsterdam, with a dominance of siboglinid polychaetes in the former and vesicomyid bivalves in the latter (Fig. 5). Although the highest SBF densities were associated with the highest methane concentrations on Amsterdam (Red), the opposite pattern was observed on Napoli, where the highest concentrations above CC were rather associated with the lowest SBF densities (Fig. 5).

\section{$\beta$-diversity patterns}

Macro- and meiofauna from both MVs did not exhibit the same $\beta$-diversity patterns (Procrustes test $m_{12}=0.274, \mathrm{p}=0.538$ for Napoli and $m_{12}=0.459, \mathrm{p}=$ 0.201 for Amsterdam and 1000 permutations). It can-
Agathotanaidae and Paraonidae in the peripheral microhabitats (Fig. 6a).

Similarly, variability was higher among microhabitats on Amsterdam (Fig. 6c). PCA and clustering allowed the identification of 3 groups (Fig. 6d). Within microhabitats, variability was lower than at Napoli, with a mean of up to $55 \%$ shared species in the Red microhabitat (Table 6). Of the taxa that contributed to the dispersion of samples in the PCA, Serpulidae polychaetes dominated CC samples, while Vesicomyidae bivalves were relatively more numerous in Red (Fig. 6c).

When considering samples from both MVs, Red from Amsterdam appeared clearly distinct from all others and showed high homogeneity between replicates (Fig. 6e,f). Among the remaining microhabitats, CC from both MVs made up a second group with Lam and Biv from Napoli, whereas the peripheral microhabitats from Napoli and Biv from Amsterdam constituted a third group that also included the Ref sites (Fig. 6e,f). Of the taxa that contributed to the dispersion of samples in the PCA, Vesicomyidae and Dorvilleidae had high relative abundances in the Red microhabitat from Amsterdam but were nearly absent from all other samples (Fig. 6e, Table 4). Serpulidae, Orbitestellidae and Demospongia were most represented in the microhabitats of the second group (Fig. 6e). Finally, Paraonidae, Cirratulidae and Agathotanaidea had higher relative abundances in the microhabitats of the third group (Fig. 6e).

The RDA performed on macrofaunal abundances of all microhabitats from both MVs explained $56.4 \%$ 

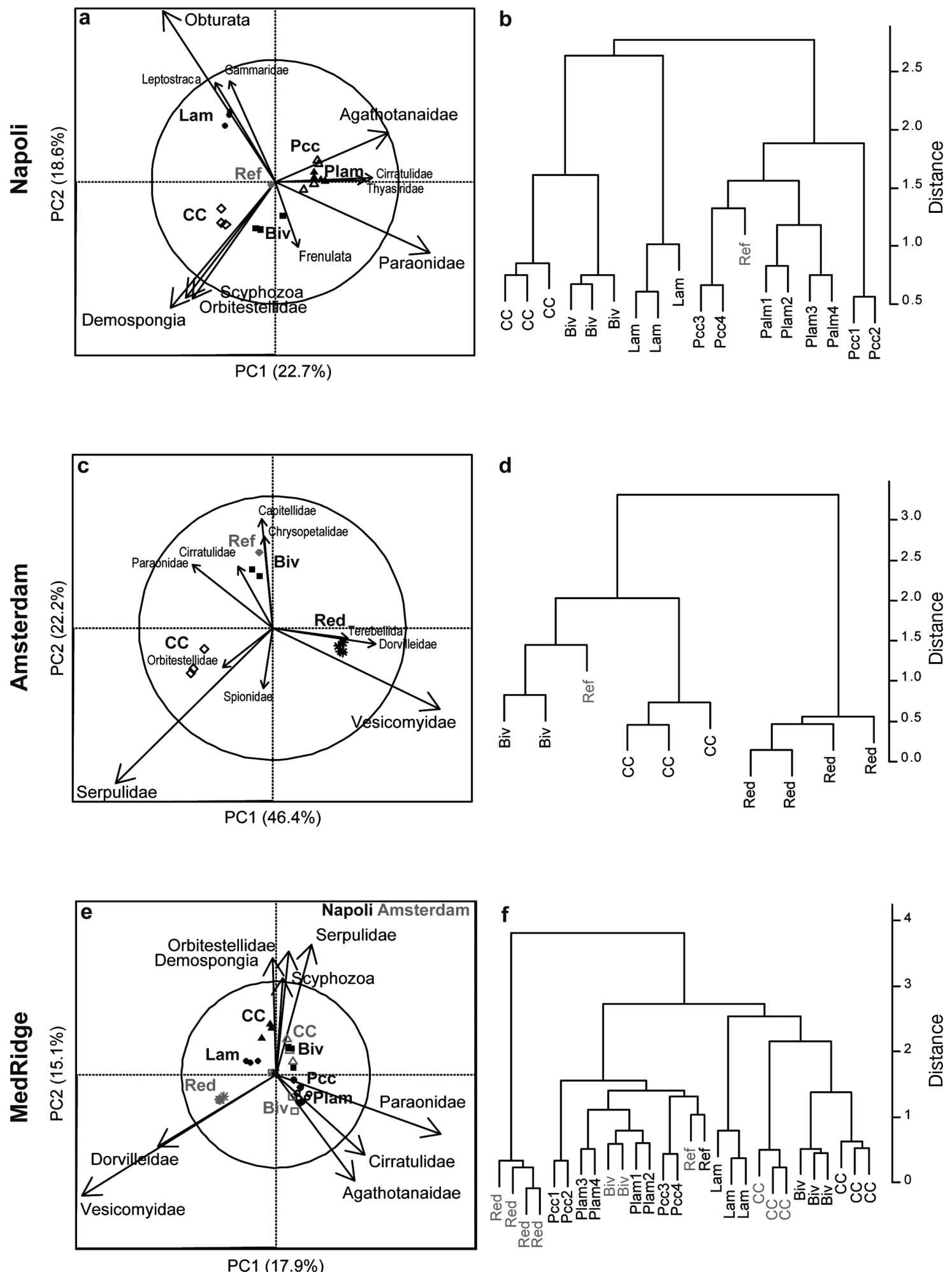

Fig. 6. Principal component analysis (PCA, scaling type 1) of Hellinger-transformed macrofaunal abundances with mixed taxonomic levels, on (a) Napoli, (c) Amsterdam and (e) both mud volcanoes (MVs) together (Mediterranean Ridge). The circle of equilibrium contribution indicates the significant contribution of the taxa with arrows longer than the radius. Ward's hierarchical clustering was performed on Hellinger-transformed macrofaunal abundances for each microhabitat type on (b) Napoli, (d) Amsterdam and (f) both MVs (Mediterranean Ridge). Biv: bivalve shells; Lam: Lamellibrachia; CC: carbonate crusts; Plam: peripheral sediments in the vicinity of Lam; PCC: peripheral sediments in the vicinity of CC; Red: reduced sediments; 
of the variance in taxonomic distribution (pseudo- $F=$ $6.26, \mathrm{p}<0.001$; Fig. 7). With the exception of $\mathrm{pH}$, the other quantitative explanatory variables (oxygen, sulphate, methane and chloride) were mostly related to the first axis. Methane and $\mathrm{pH}$ were negatively correlated to oxygen, chloride and sulphate concentrations. $\mathrm{pH}$ and chloride explained some of the variations on the second axis, as did the presence/ absence of carbonates, underlining the important distinction between hard and soft substrata. The Red microhabitat on Amsterdam, with a high contribution of Dorvilleidae and Vesicomyidae, was the most methane-rich and was differentiated from all other microhabitats. On the other hand, the Napoli peripheral sites as well as the Amsterdam Biv microhabitat were associated with high oxygen/high sulphate concentrations. The distribution along the second axis shows that the CC microhabitats on both MVs were close to Biv on Napoli and also to Lam. Taxa related to the lower part of the second axis, such as Demospongia and Serpulidae, are typical sessile fauna observed on hard substrata. Peripheral microhabitats as well as the Biv microhabitat on Amsterdam were grouped along the second axis, primarily under the influence of the presence of soft substrata (Fig. 7).

\section{DISCUSSION}

The cold seeps located along the MR are characterised by a high number of MVs and spectacular fluid emissions on the seafloor. Napoli and Amsterdam are 2 examples of active MVs that can be distinguished by the presence of brine lakes, mud flows, chaotic centres and visible fauna at their peripheries. Both MVs are located on an active margin, in the same range of depths at $\sim 2000 \mathrm{~m}$ and exhibit similar types of microhabitats, such as sediments covered by bivalve shells, reduced sediments and carbonate crusts.

In this study, most of the investigations focused on the centre of both Napoli and Amsterdam MVs. The variety of visually distinguishable habitats reflects the high spatial variability of fluid intensity on their surfaces. These visual features represent potentially different microhabitats in terms of chemical environment and faunal composition. The Napoli MV is characterised by the presence of brines due to the upward migration of fluids enriched by Messinian salt deposits (Charlou et al. 2003). Amsterdam, however, is characterised by the presence of gas hydrates (Lykousis et al. 2008). Based on the temperature gra-

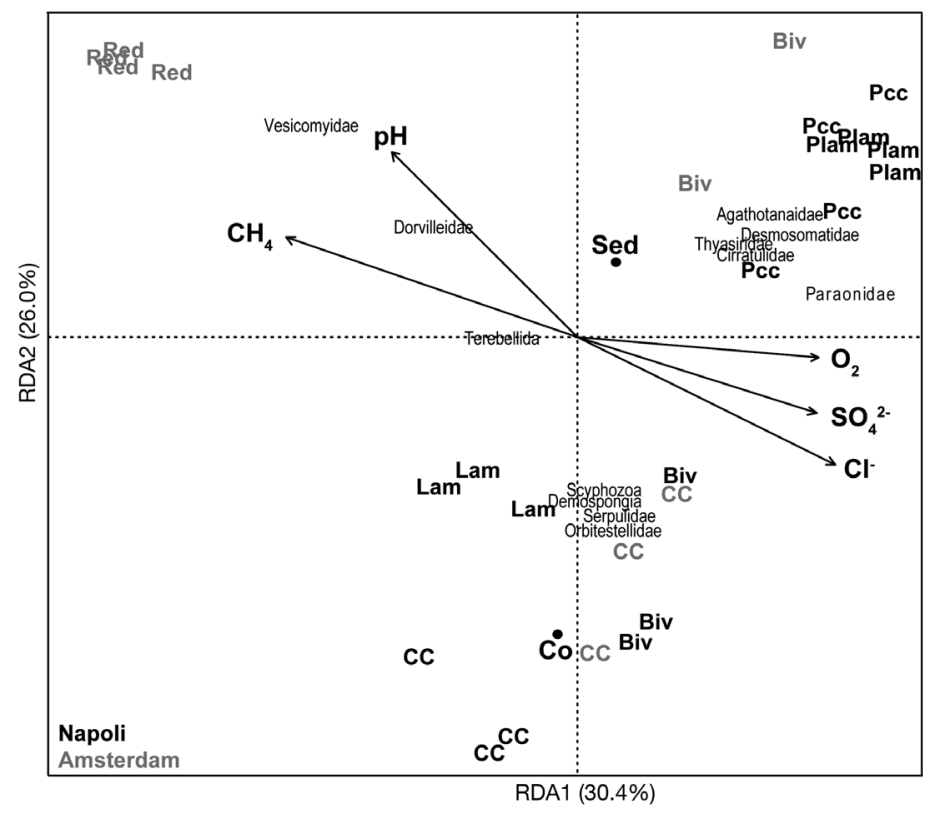

Fig. 7. Canonical redundancy analysis (RDA, scaling type 2) performed on the matrix of macrofaunal abundances with mixed taxonomic levels sampled on Napoli (black) and on Amsterdam (grey) mud volcanoes and the matrix of environmental factors (black). The 2 first axes explain $56.4 \%$ of the total variance. Vectors are represented by arrows and centroids by dots. Sed: soft sediments; Co: concretions

dients measured within the sediments in their centre, Amsterdam $\left(36^{\circ} \mathrm{C}\right.$ at $6 \mathrm{~m}$ below the seafloor) has a higher activity than Napoli $\left(14.9^{\circ} \mathrm{C}\right.$ measured at $10 \mathrm{~m}$ below the seafloor; J. P. Foucher pers. comm.). This is also supported by the highest methane concentrations that reach up to $12.45 \mathrm{mmol} \mathrm{l}^{-1}$ (Red) at Amsterdam's surface. Brine fluids also represent a major source of methane on Napoli's surface. Methane concentrations found in both MVs reach at least 3 orders of magnitude higher than in the background $(0.4 \times$ $10^{-3} \mathrm{Hmol} \mathrm{l}^{-1}$; Charlou et al. 2003) and sustain faunal communities having densities 2 orders of magnitude higher than the reference sites. Chemical and sediment instability induced by brines on Napoli prevent the establishment of faunal communities throughout this active region, therefore restricting them to peripheral areas.

\section{Community structure at the MV scale: Napoli}

The first structuring factor of the faunal distribution among microhabitats on Napoli appears to be the chemical gradients (methane, oxygen, sulphate and chloride), which are themselves related to the fluid intensity. The second factor appears to be the type of substratum (hard or soft). 
Above the CC microhabitat, which appeared to be the most constraining microhabitat on Napoli, the high methane concentration $\left(4.3 \mu \mathrm{mol} \mathrm{l}^{-1}\right)$ was associated with the lowest oxygen concentration (196.4 $\left.\mu_{\mathrm{mol} \mathrm{l}} \mathrm{l}^{-1}\right)$ encountered. Despite the lack of flux rate measurement above $\mathrm{CC}$, methane concentrations at the interface suggest an active area of fluid emissions in spite of the thick carbonate pavement. The Lam microhabitat had methane concentrations 5.6 times lower

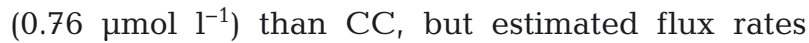
measured in Lam (from 9.3 to $63 \mathrm{~cm} \mathrm{yr}^{-1}$ ) confirmed that Lam undergoes high upward fluid fluxes. In terms of fauna, different communities inhabited CC and Lam, partly related to the type of substratum. Indeed, sessile heterotrophic taxa, such as Porifera, Actiniaria and Gastropoda dominated the CC community, while Lamellibrachia anaximandri living with thiotrophic bacteria were the most represented taxa in Lam in terms of density and biomass. Only the first centimetres of $L$. anaximandri were visible on the seafloor, while their tubes were deeply anchored within reduced sediments and may reach at least $20 \mathrm{~cm}$ in depth for the longest individuals (B. Ritt pers. obs.). They probably have access to sulphides by their posterior end (Julian et al. 1999) to fuel their endosymbionts as observed in Siboglinidae bushes in the Gulf of Mexico (Bergquist et al. 2002). Therefore, the non-detection of sulphides at the sediment surface does not preclude their production within sediments. Furthermore, the presence of $L$. anaximandri corroborates the hypothesis of the sulphide production within sediments to sustain its symbionts. This species is ubiquitous in Mediterranean seeps and relies on sulphides for its survival (Olu-Le Roy et al. 2004, Southward et al. 2011).

Despite a potential bias induced by the sampling strategy used on CC (i.e. small surface sampled, under-representation of the total fauna), diversity (richness and evenness combined) and family richness (ES50: 17 in CC versus 10 in Lam) were higher at $\mathrm{CC}$ than Lam. These results contradict our expectations, since we had assumed we would observe lower diversity in environments with higher constraints. Indeed, CC seems to provide various ecological niches for both symbiotic and heterotrophic fauna. Likewise, it appears that the environmental conditions in Lam do not enhance its faunal diversity, but contrarily, favour colonisation by a few specialised symbiotic and heterotrophic species adapted to high amounts of OM, low oxygen penetration (few millimetres) and high upward fluxes. The Lam microhabitat may constitute a complex system, associating chemical and biological reactions with advection- diffusion processes highly variable between replicates (located 1 to $2 \mathrm{~m}$ away), and as constraining as $\mathrm{CC}$. This is exemplified by the wide range of estimated flux intensity (from 9.3 to $63 \mathrm{~cm} \mathrm{yr}^{-1}$ ) and the heterogeneity of sulphate and chloride profiles that reveal multiple fluid origins (i.e. seawater, fresh water, brine). The high concentrations of organic carbon (up to $1.82 \%$ ), which are higher than those recorded in sites without seepage and at the same depth in the Mediterranean Sea (from 0.30 to $0.69 \%$ of organic carbon; Buscail \& Germain 1997, Danovaro et al. 1999), corroborate the hypothesis of high local production and turnover of OM.

The Biv microhabitat appears to have weaker fluid intensity with methane concentrations 1.5 times lower than Lam. The seepage activity at the microhabitat is also indirectly evident by the presence of Siboglinum sp. frenulates. This dominant Siboglinidae subfamily lives with sulphur-oxidising bacteria and probably also methane-oxidising bacteria (Bright \& Giere 2005, Dubilier et al. 2008, Rodrigues et al. 2011). At our study sites, the siboglinid sub-families Frenulata and Obturata did not co-occur in the same microhabitat, suggesting that they may require distinct environmental conditions. In fact, Lamellibrachia anaximandri appears to tolerate higher fluid fluxes than Siboglinum sp. However, Southward et al. (2011) observed co-occurrence at both MVs. This may suggest that the environmental conditions of our sampling sites may be more contrasted than those sampled previously by Southward et al. (2011). In addition to the presence of SBF, stable isotope signatures of the sedimented OM sampled at the summit of the Napoli MV confirm the presence of methaneinfluenced sediments ( 36\%; Carlier et al. 2010). These signatures also suggest the influence of phytoplankton in the food web ( 22\%; Carlier et al. 2010$)$. In terms of environmental conditions, Biv may be considered an intermediate microhabitat. For the fauna, Biv is close to CC due to common taxa, such as Porifera, Actiniaria and Scyphozoa, which may use the empty bivalve shells as hard substrata to colonise.

The peripheral microhabitats of Lam and CC were characterised by some of the highest oxygen concentrations (up to $221.4 \mu_{\mathrm{mol}} \mathrm{l}^{-1}$ in Plam). Peripheral microhabitats were sampled to determine possible gradients between active (Lam, CC) and peripheral (Plam, Pcc) sites on Napoli. Only slight differences in terms of methane and oxygen concentrations were observed between Lam and Plam, with values respectively reaching 0.76 and $222.5 \mu \mathrm{mol} \mathrm{l}^{-1}$ in the former and up to 0.56 and $221.4 \mu \mathrm{mol} \mathrm{l}^{-1}$ in the latter. However, they present important differences in 
advection rates, which were close to 0 in Plam, suggesting a lower input of methane and sulphides. As a result, both Lam and Plam were located at the opposite side of the chemical gradient and were inhabited by distinct communities. Indeed, Plam was dominated by Paraonidae polychaetes, a dominant family in benthic communities of deep, sandy or silty areas (Rouse \& Pleijel 2001), while Lam was dominated by the symbiont-bearing Lamellibrachia anaximandri. Concerning $\mathrm{CC}$ and $\mathrm{PCC}_{\mathrm{CC}}$ their spatial proximity was apparently their only common feature, since there was an obvious heterogeneity in methane concentrations that were up to 8 times higher above CC $\left(4.29 \mu \mathrm{mol} \mathrm{l}^{-1}\right)$ than above PCC $\left(0.50 \mu \mathrm{mol} \mathrm{l}^{-1}\right)$. To summarize, on Napoli the peripheral sites appeared to be distinct from the active sites with their relatively mild abiotic conditions that have favored high macrofaunal densities, particularly in Pcc (up to 10688 ind. $\mathrm{m}^{-2}$ ). Considering all microhabitats from the $2 \mathrm{MVs}$, the peripheral sites from Napoli appeared to present the mildest environmental conditions. Additional sampling may be useful to acquire better knowledge of the chemical gradients occurring between active and peripheral sites and to assess the relevance of the 'active' and 'peripheral' labels, which were primarily based on visual observations.

\section{Community structure at the MV scale: Amsterdam}

Similarly to Napoli, faunal distribution among microhabitats on Amsterdam appeared to be related to the chemical gradients (methane, oxygen, sulphate and chloride). The influence of the type of substratum also seemed to be the second structuring factor.

The Red microhabitat was by far the most constraining microhabitat on Amsterdam, with low oxygen concentrations $\left(188.2 \mu \mathrm{mol} \mathrm{l}^{-1}\right)$ and methane concentrations reaching $12.45 \mu \mathrm{mol} \mathrm{l^{-1 }}$. These values were the highest measured in this study, reaching nearly 3 times the concentrations observed on Napoli (CC). Red presented a wide range of methane concentrations, highlighting the heterogeneity of the fluid intensity at a small spatial scale (metres). As expected, faunal richness was lower in Red than in Biv (ES50: 4 versus 13, respectively). The highly constraining conditions (i.e. low oxygen) favour the establishment of high densities of symbiont-bearing vesicomyids, probably juveniles of Isorropodon perplexum. This species lives with sulphur-oxidising bacteria and is ubiquitous in both eastern Mediterranean Sea seep sites and the Marmara Sea (Olu-Le Roy et al. 2004, Ritt et al. 2010).
In terms of environmental conditions, the $\mathrm{CC}$ and Biv microhabitats presented slight differences. CC appeared more oxygenated (up to 202.2 versus $195.5 \mu \mathrm{mol} \mathrm{l}^{-1}$ in Biv) and less enriched in methane than Biv (up to $0.60 \mu \mathrm{mol} \mathrm{l^{-1 }}$ in $\mathrm{CC}$ compared to $0.70 \mu \mathrm{mol} \mathrm{l^{-1 }}$ in Biv). Nevertheless, despite their mild environmental conditions, the presence of SBF (Siboglinum sp., Lucinoma kazani, Thyasira striata and undetermined vesicomyids) in CC and Biv suggests the presence of seepage activities in both microhabitats. The family richness on CC was lower than expected considering that the environmental conditions are less constraining than in Red. CC, however, presented a family richness higher than that of Red (ES50: 9 in CC versus 4 in Red). Here again, the bias introduced by the sampling strategy may explain these unexpected results and limit our conclusions about the CC microhabitat. Regardless of the possible under-estimation of the faunal community on $\mathrm{CC}$, some trends can still be observed. There, the fauna is mainly represented by the Serpulidae polychaetes. Biv appears to encompass abiotic conditions that favour relatively high densities and a slightly higher richness (ES50: 13) and an observed family richness twice as important as that from other Amsterdam microhabitats ( $S_{\text {obs: }}$ 25). Additional investigations are needed to understand which parameters drive this relatively high diversity in Biv.

\section{Comparison at the scale of the Mediterranean Ridge}

In terms of global activity, the Amsterdam MV appears to be more active and unstable (Charlou et al. 2003) and constitutes a more constraining environment for faunal colonisation than the Napoli MV. At both MVs, high heterogeneity was observed not only between the different microhabitats but also between replicates of the same microhabitat. The distribution of microhabitats on these $2 \mathrm{MR}$ MVs, however, suggests that the type of habitat controls the structure of seep communities, rather than the geographical location as observed at the NDSF sites (Ritt et al. 2011). In terms of fauna, Napoli appeared to harbour higher taxonomic richness at the family level than Amsterdam. Nevertheless, faunal densities on Amsterdam were 2.3 times higher than on Napoli. This suggests more stringent environmental constraints in Amsterdam microhabitats, characterised by high methane and low oxygen concentrations. 
This study also suggests that the substratum type is the second structuring factor of the faunal composition and distribution. The CC microhabitat, however, appeared highly heterogeneous within and between sites. Indeed, CCs at both MVs presented different morphologies (Aloisi et al. 2000, 2002) and variable proportions of aragonite, dolomite and calcite (Pierre et al. 2008, 2010). Furthermore, results from CC microhabitats at both MVs must be interpreted in consideration of (1) an insufficient sampling effort to get a complete picture of the community, and (2) no direct sampling of the crust endofauna. Despite these caveats, the CC microhabitats presented unexpectedly high taxonomic richness for harsh environmental conditions, and additional samples would probably not change this trend. The study of the CC communities appears to be complex due to the difficulties encountered during sampling and the inherent characteristics of the carbonates. Indeed, the different morphologies of CCs may be considered as different stages of formation that are related to variations in seepage activity and fluid composition. It could be interesting to further investigate the faunal composition on these different carbonate morphologies to determine whether the carbonate composition influences the faunal composition.

\section{Comparison at larger scales}

Overall, among the seep sites studied in the Mediterranean Sea, the Red and CC microhabitats are commonly found (Ritt et al. 2010, 2011). Each microhabitat, however, seems unique with regard to its faunal composition, the proportion of SBF and the taxonomic richness at the family level. Similar Lamellibrachia aggregates anchored in reduced sediments have been observed in the NDSF (B. Ritt pers. obs.), but no Siboglinidae polychaetes have been observed in the Marmara Sea so far. Lam from Napoli presented similarities with the reduced sediments from the Amon MV in the eastern Province of the NDSF (1000 m depth), where the SBF is represented by Siboglinidae from both sub-families as well as by Mytilidae (Ritt et al. 2011). Similarly, the reduced sediments from Amsterdam were dominated by the vesicomyid Isorropodon perplexum as observed in the reduced sediments from the Pockmark area in the central province of the NDSF. Sulphide concentrations within Napoli and Amsterdam sediments were not available in this study, but when considering the SBF, we can expect that (1) as in the NDSF sites, sulphides are produced within Lam and Red from Napoli and Amsterdam, respectively, and (2) the fluid flow on Amsterdam may be higher than on Napoli. Indeed, sulphide concentrations reached $2.5 \mathrm{mmol} \mathrm{l}^{-1}$ at $5 \mathrm{~cm}$ depth at Amon, while $25 \mathrm{mmol}^{-1}$ was recorded at the Pockmark area where the fluid flow intensity was assumed to be higher (Ritt et al. 2011).

Once more considering the SBF, the CCs from Napoli and the Marmara Sea present the same dominant taxa, including Mytilidae and some sessile taxa such as Porifera and Cnidaria. The carbonates from the Marmara Sea also form thick pavements, which do not appear to prevent methane fluid and sulphide diffusion to fuel the dense community of sulphuroxidising Mytilidae (Ritt et al. 2012). This observation suggests that the presence of a thick pavement is not necessarily associated with past activity. The high methane concentrations above CC on Napoli corroborate this theory. However, the CCs from Napoli and the Marmara Sea differ from those from Amon, which are devoid of SBF and are likely located in an area of low fluid influence (Dupré et al. 2007, Ritt et al. 2011). As stated earlier, the carbonate composition related to the seepage activity seems to be a potential structuring factor that needs further investigation.

In terms of chemistry, methane and oxygen gradients showed opposite trends and appeared to be important structuring factors. This was also the case for symbiont-bearing species (Olu-Le Roy et al. 2007) and associated heterotrophic polychaetes (Menot et al. 2010) in the giant REGAB pockmark in the Gulf of Guinea. Substratum type is also an important parameter observed at REGAB, influencing the spatial distribution of siboglinids and vesicomyids (Olu-Le Roy et al. 2007). Napoli MV shares similarities with cold seeps of the Gulf of Mexico (Cary et al. 1989b, MacDonald et al. 1990) since it is under the influence of salt-saturated brine lakes and upward brine migration fuelled by salt deposits (Cita \& Ryan 1973, Hsu et al. 1977). However, estimated advection rates of upward fluxes on Napoli (from 9.3 to $63 \mathrm{~cm} \mathrm{yr}^{-1}$ ) are much higher than those estimated for the Gulf of Mexico (0.2 and $3.2 \mathrm{~cm} \mathrm{yr}^{-1}$; MacDonald et al. 1993, 2000). The brine lakes of Napoli, located at the centre of the MV where the activity appears high, are characterised by high salinity (82\%) and elevated chloride concentration (1380 mmol l-1; Charlou et al. 2003). Similar brine lakes have been observed in the western province of the NDSF, especially on Cheops and Chefren MVs at $3000 \mathrm{~m}$ depth. These MVs are characterised by the presence of high methane concentrations and salinity above the brines that are higher than on Napoli (Huguen et al. 2009). Brine seepage 
appears to induce sedimentary instability and to create local spots of activity, similar to what is observed in the Lam microhabitat on Napoli. No brines were observed on Amsterdam, but instability may be created by mud flows (Zitter et al. 2005) such as those detected on the Håkon Mosby MV on the Norwegian margin (Feseker et al. 2008). This well-studied MV undergoes episodic mud eruptions that generate sedimentary and chemical instability, influencing the distribution of the benthic fauna in concentric belts around the summit (Jerosch et al. 2007). At the Napoli and Amsterdam MVs, the visible fauna is located on particular microhabitats on their active summits but not necessarily associated with dynamic structures such as brines or mud flows (Olu-Le Roy et al. 2004, Zitter et al. 2005). Further investigations are needed to enhance our understanding of the faunal distribution on Napoli and Amsterdam MVs. Extending the sampling protocol to other MVs in the Olimpi Field and the Anaximander Mountains should further increase our understanding of regional distribution patterns and how they are linked with larger-scale processes. Furthermore, meio- and macrofauna appear to be differently influenced by the nature of the microhabitats and underlying physico-chemical factors, but this may be attributable to the incomplete sampling of meiofauna during this study. Further investigations, focusing on meiofauna with an appropriate sampling strategy, may determine whether this faunal compartment behaves in the same way in relation to the conditions of the environment as the macrofauna.

Acknowledgements. The captain and crew of the RV 'Pourquoi pas?' as well as the pilots of the ROV 'Victor6000' are acknowledged for their dedicated assistance and for contributing to the success of the MEDECO cruise. The chief scientist of this cruise leg 1 (2007) was J.S. The faunal samples were identified by an international network of taxonomists: R. von Cosel (Muséum National d'Histoire Naturelle de Paris); S. Gofas (Department of Animal Biology of Málaga University); C. Plum (German Centre for Marine Biodiversity Research); M. Blazewicz-Paszkowycz (University of Lodz); S. Vasilenkó (Russian Academy of Sciences, Moscow); A. Mironov and G. M. Vinogradov (P. P. Shirshov Institute of Oceanology, Moscow); D. Ivanov (Zoological Museum of Moscow State University); N. Sanamyan (Kamchatka Branch of the Pacific Institute of Geography, Petropavlovsk-Kamchatsky); E. Shornikov and M. Malyutina (Institute of Marine Biology, Vladivostok); and G. Vantsetti Murina (Institute of Biology of the Southern Seas National Academy of Sciences, Ukraine). We also thank P. Pignet for valuable help with ion analyses. The bathymetric maps were made with the data acquired and processed by B. Loubrieu (Ifremer). We also thank the anonymous reviewers for their comments that improved the manuscript. The first version of the manuscript was professionally edited by C. Engel-Gautier. B.R.'s thesis, supervised by J.S. and D.D., was entirely funded by the French In- stitute for the Exploitation of the Sea (Ifremer). This research project benefited from funds from the HERMES and HERMIONE European projects (contract nos. 511234 and 226354) as well as from the ANR DEEP-OASES (ANR06BDV005) and support from the GDR ECCHIS.

\section{LITERATURE CITED}

Aloisi G, Pierre C, Rouchy JM, Foucher JP, Woodside J (2000) Methane-related authigenic carbonates of eastern Mediterranean Sea mud volcanoes and their possible relation to gas hydrate destabilisation. Earth Planet Sci Lett 184:321-338

Aloisi G, Bouloubassi I, Heijs SK, Pancost RD and others (2002) $\mathrm{CH}_{4}$-consuming microorganisms and the formation of carbonate crusts at cold seeps. Earth Planet Sci Lett 203:195-203

Barnes H, Blackstock J (1973) Estimation of lipids in marine animals and tissues: detailed investigation of the sulphophosphovanilun method for 'total' lipids. J Exp Mar Biol Ecol 12:103-118

Barry JP, Kochevar RE, Baxter CH (1997) The influence of pore-water chemistry and physiology in the distribution of vesicomyid clams at cold seeps in Monterey Bay: implications for patterns of chemosynthetic community organization. Limnol Oceanogr 42:318-328

Bellaiche G, Loncke L, Gaullier V, Mascle J and others (2001) The Nile Cone and its channel system: new results after the Fanil cruise. C R Acad Sci Série II Fascic Sci Terre Planètes 333:399-404

Bergquist DC, Urcuyo IA, Fisher CR (2002) Establishment and persistence of seep vestimentiferan aggregations on the upper Louisiana slope of the Gulf of Mexico. Mar Ecol Prog Ser 241:89-98

Bright M, Giere O (2005) Microbial symbiosis in Annelida. Symbiosis 38:1-45

> Brink RHJ, Dubach P, Lynch DL (1960) Measurement of carbohydrates in soil hydrolyzates with anthrone. Soil Sci 89:157-166

Brissac T, Rodrigues CF, Gros O, Duperron S (2011) Characterization of bacterial symbioses in Myrtea sp. (Bivalvia: Lucinidae) and Thyasira sp. (Bivalvia: Thyasiridae) from a cold seep in the Eastern Mediterranean. Mar Ecol 32: 198-210

- Buscail R, Germain C (1997) Present-day organic matter sedimentation on the NW Mediterranean margin: importance of off-shelf export. Limnol Oceanogr 42:217-229

Camerlenghi A, Cita MB, Hieke W, Ricchiuto TS (1992) Geological evidence for mud diapirism on the Mediterranean Ridge accretionary complex. Earth Planet Sci Lett 109:493-506

> Campbell KA (2006) Hydrocarbon seep and hydrothermal vent paleoenvironments and paleontology: past developments and future research directions. Palaeogeogr Palaeoclimatol Palaeoecol 232:362-407

Caprais JC, Lanteri N, Crassous P, Noël P and others (2010) CALMAR - a new submersible-operated benthic chamber: first application in the cold-seep environment of the Napoli mud volcano (Mediterranean Sea). Limnol Oceanogr Methods 8:304-312

Carlier A, Ritt B, Rodrigues C, Sarrazin J, Olu K, Grall J, Clavier J (2010) Heterogeneous energetic pathway and carbon sources for deep eastern Mediterranean coldseep communities. Mar Biol 157:2545-2565 
Cary SC, Vetter RD, Felbeck H (1989a) Habitat characterization and nutritional strategies of the endosymbiontbearing bivalve Lucinoma aequizonata. Mar Ecol Prog Ser 55:31-45

> Cary C, Fry B, Felbeck H, Vetter RD (1989b) Multiple trophic resources for a chemoautotrophic community at a cold water brine seep at the base of the Florida Escarpment. Mar Biol 100:411-418

Cauwet G, Gadel F, Sierra MMD, Donard O, Ewald M (1990) Contribution of the Rhône River to organic carbon inputs to the northwestern Mediterranean Sea. Cont Shelf Res 10:1025-1037

> Charlou JL, Donval JP, Zitter T, Roy N, Jean-Baptiste P, Foucher JP, Woodside J (2003) Evidence of methane venting and geochemistry of brines on mud volcanoes of the eastern Mediterranean Sea. Deep-Sea Res I 50:941-958

Cita MB, Camerlenghi A (1990) The Mediterranean Ridge as an accretionary prism in collisional context. Mem Soc Geol Ital 45:463-480

Cita MB, Ryan WBF (1973) Time scale and general synthesis. US Govt Printing Office, Washington, DC

Cita MB, Ryan WBF, Paggi L (1981) Prometheus mud breccia. An example of shale diapirism in the western Mediterranean Ridge. Ann Geol Pays Hell 13:37-49

> Coleman DF, Ballard RD (2001) A highly concentrated region of cold hydrocarbon seeps in the southeastern Mediterranean Sea. Geo-Mar Lett 21:162-167

> Cordes EE, Becker EL, Hourdez S, Fisher CR (2010) Influence of foundation species, depth, and location on diversity and community composition at Gulf of Mexico lowerslope cold seeps. Deep-Sea Res II 57:1870-1881

> Corselli C, Basso D (1996) First evidence of benthic communities based on chemosynthesis on the Napoli mud volcano (eastern Mediterranean). Mar Geol 132:227-239

> Dando PR, Southward AJ (1986) Chemoautotrophy in bivalve mollusks of the genus Thyasira. J Mar Biol Assoc UK 66:915-929

> Dando PR, Southward AJ, Southward EC, Lamont P, Harvey $\mathrm{R}$ (2008) Interactions between sediment chemistry and frenulate pogonophores (Annelida) in the north-east Atlantic. Deep-Sea Res I 55:966-996

> Danovaro R, Marrale D, Della Croce N, Parodi P, Fabiano M (1999) Biochemical composition of sedimentary organic matter and bacterial distribution in the Aegean Sea: trophic state and pelagic-benthic coupling. J Sea Res 42: $117-129$

> Dubilier N, Bergin C, Lott C (2008) Symbiotic diversity in marine animals: the art of harnessing chemosynthesis. Nat Rev Microbiol 6:725-740

> Duperron S, Lorion J, Samadi S, Gros O, Gaill F (2009) Symbioses between deep-sea mussels (Mytilidae: Bathymodiolinea) and chemosynthetic bacteria: diversity, function and evolution. C R Biol 332:298-310

> Dupré S, Woodside J, Foucher JP, de Lange G and others (2007) Seafloor geological studies above active gas chimneys off Egypt (Central Nile deep sea fan). Deep-Sea Res I 54:1146-1172

> Feseker T, Foucher JP, Harmegnies F (2008) Fluid flow or mud eruptions? Sediment temperature distributions on Håkon Mosby mud volcano, SW Barents Sea slope. Mar Geol 247:194-207

Fichez R (1991) Composition and fate of organic matter in submarine cave sediments - implications for the biogeochemical cycle of organic carbon. Oceanol Acta 14:369-377

Gauthier O, Sarrazin J, Desbruyères D (2010) Measure and mis-measure of species diversity in deep-sea chemosynthetic communities. Mar Ecol Prog Ser 402:285-302

Hessler RR, Jumars PA (1974) Abyssal community analysis from replicate box cores in the central North Pacific. Deep-Sea Res 21:185-209

Hovland M, Gardner JV, Judd AG (2002) The significance of pockmarks to understanding fluid flow processes and geohazards. Geofluids 2:127-136

Hsu KJ, Montadert L, Bernoulli D, Cita MB and others (1977) History of the Mediterranean salinity crisis. Nature 267: 399-403

> Huguen C, Mascle J, Chaumillon E, Kopf A, Woodside J, Zitter T (2004) Structural setting and tectonic control of mud volcanoes from the Central Mediterranean Ridge (Eastern Mediterranean). Mar Geol 209:245-263

Huguen C, Mascle J, Woodside J, Zitter T, Foucher JP (2005) Mud volcanoes and mud domes of the Central Mediterranean Ridge: near-bottom and in situ observations. Deep-Sea Res I 52:1911-1931

> Huguen C, Foucher JP, Mascle J, Ondreas H and others (2009) Menes Caldera, a highly active site of brine seepage in the Eastern Mediterranean Sea: 'in situ' observations from the NAUTINIL expedition (2003). Mar Geol 261:138-152

Ivanov MK, Limonov AF, vanWeering TCE (1996) Comparative characteristics of the Black Sea and Mediterranean Ridge mud volcanoes. Mar Geol 132:253-271

Jaccard P (1901) Distribution de la flore alpine dans le Bassin des Dranses et dans quelques régions voisines. Bull Soc Vaud Sci Nat 37:241-272

Jackson DA (1995) PORTEST: a PROcustean randomization TEST of community environment concordance. Ecosciences 2:297-303

Jensen P (1992) 'An enteropneusts nest' — results of the burrowing traits by the deep-sea acorn worm Stereobalanus canadensis (Spengel). Sarsia 77:125-129

- Jerosch K, Schluter M, Foucher JP, Allais AG, Klages M, Edy C (2007) Spatial distribution of mud flows, chemoautotrophic communities, and biogeochemical habitats at Håkon Mosby Mud Volcano. Mar Geol 243:1-17

Judd AG, Hovland M (2007) Seabed fluid flow - the impact on geology, biology and the marine environment. Cambridge University Press, Cambridge

Julian D, Gaill F, Wood E, Arp AJ, Fisher CR (1999) Roots as a site of hydrogen sulfide uptake in the hydrocarbon seep vestimentiferan Lamellibrachia sp. J Exp Biol 202: 2245-2257

Kaltin S, Haraldsson C, Anderson LG (2005) A rapid method for determination of total dissolved inorganic carbon in seawater with high accuracy and precision. Mar Chem 96:53-60

Kindt R, Coe R (2005) Tree diversity analysis. A manual and software for common statistical methods for ecological and biodiversity studies. World Agroforestry Centre (ICRAF), Nairobi

Koleff P, Gaston KJ, Lennon JJ (2003) Measuring beta diversity for presence-absence data. J Anim Ecol 72: 367-382

Krylova EM, Sahling H (2010) Vesicomyidae (Bivalvia): current taxonomy and distribution. PLoS ONE 5:e9957

> Kvenvolden KA, Rogers BW (2005) Gaia's breath-global methane exhalations. Mar Pet Geol 22:579-590

> Legendre P, Gallagher ED (2001) Ecologically meaningful transformations for ordination of species data. Oecologia 129:271-280 
Levin LA (2005) Ecology of cold seep sediments: interactions of fauna with flow, chemistry and microbes. Oceanogr Mar Biol Annu Rev 43:1-46

Levin LA, Gage JD (1998) Relationships between oxygen, organic matter and the diversity of bathyal macrofauna. Deep-Sea Res II 45:129-163

Levin LA, Ziebis W, Mendoza GF, Growney VA and others (2003) Spatial heterogeneity of macrofauna at northern California methane seeps: influence of sulfide concentration and fluid flow. Mar Ecol Prog Ser 265:123-139

Levin LA, Mendoza GF, Gonzalez JP, Thurber AR, Cordes EE (2010) Diversity of bathyal macrofauna on the northeastern Pacific margin: the influence of methane seeps and oxygen minimum zones. Mar Ecol 31:94-110

Limonov AF, Woodside JM, Cita MB, Ivanov MK (1996) The Mediterranean Ridge and related mud diapirism: a background. Mar Geol 132:7-19

Loncke L, Mascle J, Fanil Scientific Parties (2004) Mud volcanoes, gas chimneys, pockmarks and mounds in the Nile deep-sea fan (Eastern Mediterranean): geophysical evidences. Mar Pet Geol 21:669-689

Lykousis V, Alexandri S, Woodside J, De Lange G and others (2008) Mud volcanoes and gas hydrates in the Anaximander Mountains (Eastern Mediterranean Sea). Mar Pet Geol 26:1-19

> MacDonald IR, Reilly JF, Guinasso NL, Brooks JM, Carney RS, Bryant WA, Bright TJ (1990) Chemosynthetic mussels at a brine-filled pockmark in the Northern Gulf of Mexico. Science 248:1096-1099

> MacDonald IR, Guinasso NL Jr, Ackleson SG, Amos JF, Duckworth R, Sassen R, Brooks JM (1993) Natural oil slicks in the Gulf of Mexico visible from space. J Geophys Res 98:16351-16364

MacDonald IR, Buthman DB, Sager WW, Peccini MB, Guinasso NL Jr (2000) Pulsed oil discharge from a mud volcano. Geology 28:907-910

Mascle J, Zitter T, Bellaiche G, Droz L, Gaullier V, Loncke L (2001) The Nile deep sea fan: preliminary results from a swath bathymetry survey. Mar Pet Geol 18:471-477

Mascle J, Sardou O, Loncke L, Migeon S, Camera L, Gaullier V (2006) Morphostructure of the Egyptian continental margin: insights from swath bathymetry surveys. Mar Geophys Res 27:49-59

Menot L, Galéron J, Olu K, Caprais JC, Crassous P, Khripounoff A, Sibuet M (2010) Spatial heterogeneity of macrofaunal communities in and near a giant pockmark area in the deep Gulf of Guinea. Mar Ecol 31:78-93

Milkov AV (2000) Worldwide distribution of submarine mud volcanoes and associated gas hydrates. Mar Geol 167: $29-42$

- Niemann H, Losekann T, de Beer D, Elvert M and others (2006) Novel microbial communities of the Haakon Mosby mud volcano and their role as a methane sink. Nature 443:854-858

Oksanen J, Blanchet FG, Kindt R, Legendre P and others (2012) vegan: community ecology package — ordination methods, diversity analysis and other functions for community and vegetation ecologists. Available at http: //cran.r-project.org/, http://vegan.r-forge.r-project.org/

Oliver G, Rodrigues C, Cunha MR (2011) Chemosymbiotic bivalves from the mud volcanoes of the Gulf of Cadiz. ZooKeys 113:1-38

Olu K, Lance S, Sibuet M, Henry P, Fiala-Medioni A, Dinet A (1997) Cold seep communities as indicators of fluid expulsion patterns through mud volcanoes seaward of the Barbados accretionary prism. Deep-Sea Res I 44: 811-819

> Olu-Le Roy K, Sibuet M, Fiala-Médioni A, Gofas S and others (2004) Cold seep communities in the deep eastern Mediterranean Sea: composition, symbiosis and spatial distribution on mud volcanoes. Deep-Sea Res I 51: 1915-1936

Olu-Le Roy K, Caprais JC, Fifis A, Fabri MC and others (2007) Cold-seep assemblages on a giant pockmark off West Africa: spatial patterns and environmental control. Mar Ecol 28:115-130

> Paull CK, Hecker B, Commeau R, Freeman-Lynde RP and others (1984) Biological communities at the Florida Escarpment resemble hydrothermal vent taxa. Science 226:965-967

Peres-Neto PR, Jackson DA (2001) How well do multivariate data sets match? The advantages of a Procrustean superimposition approach over the Mantel test. Oecologia 129: 169-178

Pierre C, Bayon G, Blanc-Valleron MM, Rouchy JM and others (2008) Authigenic carbonate crusts from active cold seep sites in the Eastern Mediterranean. New results from the MEDECO cruise (HERMES Project). In: 9th International Conference on Gas in Marine Sediments, Bremen: Book of Abstracts. University of Bremen, p 50

Pierre C, Blanc-Valleron MM, Bouloubassi I, Cagatay MN and others (2010) Methane-related carbonates from cold seeps of eastern Mediterranean and Marmara Sea. Rapp Comm Int Mer Mediterr 39:57

R Development Core Team (2012) R: a language and environment for statistical computing. R Foundation for Statistical Computing, Vienna

> Ritt B, Sarrazin J, Caprais JC, Noël P and others (2010) First insights into the structure and environmental setting of cold-seep communities in the Marmara Sea. Deep-Sea Res I 57:1120-1136

Ritt B, Pierre C, Gauthier O, Wenzhoefer F, Boetius A, Sarrazin J (2011) Diversity and distribution of cold-seep fauna associated with different geological and environmental settings at mud volcanoes and pockmarks of the Nile Deep-Sea Fan. Mar Biol 158:1187-1210

Ritt B, Duperron S, Lorion J, Lazar CS, Sarrazin J (2012) Integrative study of a new cold-seep mussel (Mollusca: Bivalvia) associated with chemosynthetic symbionts in the Marmara Sea. Deep-Sea Res I 67:121-132

Rodrigues CF, Hilario A, Cunha MR, Weightman AJ, Webster G (2011) Microbial diversity in Frenulata (Siboglinidae, Polychaeta) species from mud volcanoes in the Gulf of Cadiz (NE Atlantic). Antonie Leeuwenhoek 100:83-98

Rouse GW, Pleijel F (2001) Polychaetes. Oxford University Press, Oxford

Sahling H, Rickert D, Lee RW, Linke P, Suess E (2002) Macrofaunal community structure and sulfide flux at gas hydrate deposits from the Cascadia convergent margin, NE Pacific. Mar Ecol Prog Ser 231:121-138

Salas C, Woodside J (2002) Lucinoma kazani n. sp. (Mollusca: Bivalvia): evidence of a living benthic community associated with a cold seep in the Eastern Mediterranean Sea. Deep-Sea Res I 49:991-1005

> Sarradin PM, Caprais JC (1996) Analysis of dissolved gases by headspace sampling gas chromatography with column and detector switching. Preliminary results. Anal Commun 33:371-373

Sibuet M, Olu K (1998) Biogeography, biodiversity and fluid dependence of deep-sea cold-seep communities at active 
and passive margins. Deep-Sea Res II 45:517-567

Sibuet M, Olu-Le Roy K (2002) Cold seep communities on continental margins: structure and quantitative distribution relative to geological and fluid venting patterns. In: Wefer G, Billett D, Hebbeln D, Jørgensen BB, Schlüter $M$, Van Weering TJ (ed) Ocean margin systems. Springer Verlag, Berlin, p 235-251

Southward EC, Andersen AC, Hourdez S (2011) Lamellibrachia anaximandri n. sp., a new vestimentiferan tubeworm (Annelida) from the Mediterranean, with notes on frenulate tubeworms from the same habitat. Zoosystema 33:245-279

Stevenson FJ, Cheng CN (1970) Amino acids in sediments: recovery by acid hydrolysis and quantitative estimation by a colorimetric procedure. Geochim Cosmochim Acta 34:77-88

Thistle D (2003) The deep-sea floor: an overview. In: Tyler PA (ed) Ecosystems of the deep oceans. Ecosystems of the world, Vol 28. Elsevier Science, Amsterdam, p 5-37

> Van Gaever S, Moodley L, de Beer D, Vanreusel A (2006) Meiobenthos at the Arctic Håkon Mosby Mud Volcano, with a parental-caring nematode thriving in sulphiderich sediments. Mar Ecol Prog Ser 321:143-155

Vuillemin R, Le Roux D, Dorval P, Bucas K and others (2009) CHEMINI: a new in situ CHEmical MINIaturized analyzer. Deep-Sea Res I 56:1391-1399

Editorial responsibility: Matthias Seaman, Oldendorf/Luhe, Germany
Werne JP, Haese RR, Zitter T, Aloisi G and others (2004) Life at cold seeps: a synthesis of biogeochemical and ecological data from Kazan mud volcano, eastern Mediterranean Sea. Chem Geol 205:367-390

Winkler LW (1888) Die Bestimmung des im Wasser gelösten Sauerstoffes. Ber Dtsch Chem Ges 21:2843-2854

Woodside JM, Ivanov MK, Limonov AF (1998) Shallow gas and gas hydrates in the Anaximander Mountains regions, eastern Mediterranean Sea. In: Henriet JP, Mienert J (eds) Gas hydrates: relevance to world margin stability and climate change. Geological Society, London, p 177-193

Woodside JM, Mascle J, Zitter TAC, Limonov AF, Ergun M, Volkonskaia A (2002) The Florence Rise, the Western Bend of the Cyprus Arc. Mar Geol 185:177-194

Zitter T (2004) Mud volcanism and fluid emissions in Eastern Mediterranean neotectonic zones. Faculty of Earth and Life Science, Free University of Amsterdam, Amsterdam

> Zitter TAC, Woodside JM, Mascle J (2003) The Anaximander Mountains: a clue to the tectonics of southwest Anatolia. Geol J 38:375-394

> Zitter TAC, Huguen C, Woodside JM (2005) Geology of mud volcanoes in the eastern Mediterranean from combined sidescan sonar and submersible surveys. Deep-Sea Res I 52:457-475

Submitted: October 10, 2011; Accepted: June 22, 2012

Proofs received from author(s): October 1, 2012 